\title{
EXTENSÃO UNIVERSITÁRIA UM CAMINHO DE INTEGRAÇÃO E APRENDIZAGEM
}

ORGANIZADORAS

Bruna Gardenal Fina

Camila Aoki 


\section{EXTENSÃO UNIVERSITÁRIA UM CAMINHO DE INTEGRAÇÃO E APRENDIZAGEM}

ORGANIZADORAS

Bruna Gardenal Fina

Camila Aoki 
2021 - Editora Amplla

Copyright (C) Editora Amplla

Copyright do Texto (C) 2021 Os autores

Copyright da Edição (C) 2021 Editora Amplla

Editor Chefe: Leonardo Pereira Tavares

Diagramação: Higor Costa de Brito

Edição de Arte: Higor Costa de Brito

Revisão: Os autores

Extensão universitária: um caminho de integração e aprendizagem está licenciado sob CC BY 4.0.

(c) (i)

fins comerciais.

Esta licença exige que as reutilizações deem crédito aos criadores. Ele permite que os reutilizadores distribuam, remixem, adaptem e construam o material em qualquer meio ou formato, mesmo para

O conteúdo da obra e seus dados em sua forma, correção e confiabilidade são de responsabilidade exclusiva dos autores, não representando a posição oficial da Editora Amplla. É permitido o download da obra e o compartilhamento desde que sejam atribuídos créditos aos autores. Todos os direitos para esta edição foram cedidos à Editora Amplla pelos autores.

ISBN: 978-65-88332-57-3

DOI: 10.51859/amplla.euc573.1121-0

Editora Amplla

Campina Grande - PB - Brasil contato@ampllaeditora.com.br www.ampllaeditora.com.br 
Andréa Cátia Leal Badaró - Universidade Tecnológica Federal do Paraná

Andréia Monique Lermen - Universidade Federal do Rio Grande do Sul

Antoniele Silvana de Melo Souza - Universidade Estadual do Ceará

Bergson Rodrigo Siqueira de Melo - Universidade Estadual do Ceará

Bruna Beatriz da Rocha - Instituto Federal do Sudeste de Minas Gerais

Caio César Costa Santos - Universidade Federal de Sergipe

Carina Alexandra Rondini - Universidade Estadual Paulista

Carla Caroline Alves Carvalho - Universidade Federal de Campina Grande

Carlos Augusto Trojaner - Prefeitura de Venâncio Aires

Carolina Carbonell Demori - Universidade Federal de Pelotas

Cícero Batista do Nascimento Filho - Universidade Federal do Ceará

Clécio Danilo Dias da Silva - Universidade Federal do Rio Grande do Norte

Daniela de Freitas Lima - Universidade Federal de Campina Grande

Denise Barguil Nepomuceno - Universidade Federal de Minas Gerais

Dylan Ávila Alves - Instituto Federal Goiano

Edson Lourenço da Silva - Instituto Federal de Educação, Ciência e Tecnologia do Piauí

Elane da Silva Barbosa - Universidade Estadual do Ceará

Érica Rios de Carvalho - Universidade Católica do Salvador

Gilberto de Melo Junior - Instituto Federal do Pará

Higor Costa de Brito - Universidade Federal de Campina Grande

Italan Carneiro Bezerra - Instituto Federal da Paraíba Ivo Batista Conde - Universidade Estadual do Ceará

Jaqueline Rocha Borges dos Santos - Universidade Federal Rural do Rio de Janeiro
Jessica Wanderley Souza do Nascimento - Instituto de Especialização do Amazonas

João Henriques de Sousa Júnior - Universidade Federal de Santa Catarina

João Manoel Da Silva - Universidade Federal de Alagoas

João Vitor Andrade - Universidade de São Paulo

Joilson Silva de Sousa - Instituto Federal do Rio Grande do Norte

José Cândido Rodrigues Neto - Universidade Estadual da Paraíba

Jose Henrique de Lacerda Furtado - Instituto Federal do Rio de Janeiro

Josenita Luiz da Silva - Faculdade Frassinetti do Recife

Josiney Farias de Araújo - Universidade Federal do Pará

Karina de Araújo Dias - SME/Prefeitura Municipal de Florianópolis

Laíze Lantyer Luz - Universidade Católica do Salvador

Lindon Johnson Pontes Portela - Universidade Federal do Oeste do Pará

Lucas Capita Quarto - Universidade Federal do Oeste do Pará

Lúcia Magnólia Albuquerque Soares de Camargo Unifacisa Centro Universitário

Luciana de Jesus Botelho Sodré dos Santos Universidade Estadual do Maranhão

Luís Paulo Souza e Souza - Universidade Federal do Amazonas

Luiza Catarina Sobreira de Souza - Faculdade de Ciências Humanas do Sertão Central

Manoel Mariano Neto da Silva - Universidade Federal de Campina Grande

Marcelo Alves Pereira Eufrasio - Centro Universitário Unifacisa

Marcelo Williams Oliveira de Souza - Universidade Federal do Pará

Marcos Pereira dos Santos - Faculdade Rachel de Queiroz

Marcus Vinicius Peralva Santos - Universidade Federal da Bahia 
Marina Magalhães de Morais - Universidade Federal de Campina Grande

Nadja Maria Mourão - Universidade do Estado de Minas Gerais

Natan Galves Santana - Universidade Paranaense

Nathalia Bezerra da Silva Ferreira - Universidade do Estado do Rio Grande do Norte

Neide Kazue Sakugawa Shinohara - Universidade Federal Rural de Pernambuco

Neudson Johnson Martinho - Faculdade de Medicina da Universidade Federal de Mato Grosso

Patrícia Appelt - Universidade Tecnológica Federal do Paraná

Paulo Henrique Matos de Jesus - Universidade Federal do Maranhão

Rafael Rodrigues Gomides - Faculdade de Quatro Marcos

Reângela Cíntia Rodrigues de Oliveira Lima Universidade Federal do Ceará

Rebeca Freitas Ivanicska - Universidade Federal de Lavras

Renan Monteiro do Nascimento - Universidade de Brasília

Ricardo Leoni Gonçalves Bastos - Universidade Federal do Ceará

Rodrigo da Rosa Pereira - Universidade Federal do Rio Grande

Sabrynna Brito Oliveira - Universidade Federal de Minas Gerais
Samuel Miranda Mattos - Universidade Estadual do Ceará

Shirley Santos Nascimento - Universidade Estadual Do Sudoeste Da Bahia

Silvana Carloto Andres - Universidade Federal de Santa Maria

Silvio de Almeida Junior - Universidade de Franca

Tatiana Paschoalette Rodrigues Bachur Universidade Estadual do Ceará

Telma Regina Stroparo - Universidade Estadual do Centro-Oeste

Thayla Amorim Santino - Universidade Federal do Rio Grande do Norte

Virgínia Maia de Araújo Oliveira - Instituto Federal da Paraíba

Virginia Tomaz Machado - Faculdade Santa Maria de Cajazeiras

Walmir Fernandes Pereira - Miami University of Science and Technology

Wanessa Dunga de Assis - Universidade Federal de Campina Grande

Wellington Alves Silva - Universidade Estadual de Roraima

Yáscara Maia Araújo de Brito - Universidade Federal de Campina Grande

Yasmin da Silva Santos - Fundação Oswaldo Cruz

Yuciara Barbosa Costa Ferreira - Universidade Federal de Campina Grande 
2021 - Editora Amplla

Copyright $(C$ Editora Amplla

Copyright do Texto @ 2021 Os autores

Copyright da Edição @ 2021 Editora Amplla

Editor Chefe: Leonardo Pereira Tavares

Diagramação: Higor Costa de Brito

Edição de Arte: Higor Costa de Brito

Revisão: Os autores

Dados Internacionais de Catalogação na Publicação (CIP)

Extensão universitária [livro eletrônico]: um caminho de integração e aprendizagem / organização Bruna Gardenal Fina, Camila Aoki. -- Campina Grande : Editora Amplla, 2021.

$66 \mathrm{p}$.

Formato: $\mathrm{PDF}$

ISBN : $978-65-88332-57-3$

1. Ciências - Estudo e ensino. 2. Pesquisa - Projeto de extensão I. Fina, Bruna Gardenal. II. Aoki, Camila. III. Título.

$\mathrm{CDD}-378$

Sueli Costa - Bibliotecária - CRB-8/5213

(SC Assessoria Editorial, SP, Brasil)

Índices para catálogo sistemático:

1. Ensino superior 


\section{APRESENTAÇ̃̃O}

As atividades de Extensão pressupõem a troca de saberes e um maior entrosamento entre seus pares. Estimula a ação conjunta e ao mesmo tempo o protagonismo de seus participantes.

O Projeto "Aquidauana: um rio de saberes desaguando no Pantanal" oportunizou aos alunos e professores da Educação Básica e também aos acadêmicos de graduação, diversas ações que vieram a contribuir com seu aperfeiçoamento estudantil/profissional.

Aos alunos da Educação básica foi proporcionado intenso contato com o método científico, desmistificando o pedestal em que os cientistas são imaginados e permitindo que os mesmos realizassem diversos experimentos, estimulando o método pesquisa-ação, tanto em atividades externas (ambientes alternativos) como em laboratórios. Houve contato frequente dos alunos com os acadêmicos, pós-graduandos, professores e pesquisadores da UFMS/CPAQ, estabelecendo sempre o diálogo e sanando as dúvidas/curiosidades dos mesmos.

As atividades externas estimularam a integração entre os participantes, proporcionoulhes maior autonomia, o desenvolvimento de atividades coletivas e a reflexão sobre a responsabilidade de cada um com sua própria aprendizagem. Os temas abordados ganharam significância para os alunos e houve muitos relatos de melhoria do comportamento nas escolas, refletindo também em suas avaliações/notas e para além, em suas posturas de vida, tornandose pessoas mais críticas, tanto em relação ao seu processo educacional como também como cidadãos.

Para os professores da Educação básica o Projeto representou uma oportunidade de repensar as metodologias de ensino adotadas e as novas abordagens possíveis e exequíveis, além de proporcionar intensa troca de informações e novas aprendizagens. Proporcionou atualização de conteúdos e foi enfatizada a importância das ações cotidianas como forma de integração e estímulo à uma aprendizagem significativa e prazerosa, além da necessidade contínua de capacitação aos profissionais da Educação Básica.

Alunos e professores da Educação Básica participaram de inúmeras atividades de divulgação dos conteúdos desenvolvidos no Projeto e puderam sentir a responsabilidade e a sensação prazerosa do dever cumprido.

Para os acadêmicos da graduação o Projeto de Extensão proporcionou o contato cotidiano com a escola, permitindo um observar e fazer diferenciado, além da compreensão da 
dimensão pedagógica e suas abordagens. Muitos hoje são professores e atuam na Educação Básica, aplicando um pouco do que puderam vivenciar durante o Projeto em seu dia-a-dia. 0 contato com os pós-graduandos serviu de estímulo para a busca contínua da aprendizagem, e muitos desses acadêmicos, hoje já são Especialistas, Mestres e/ou doutorandos em diferentes áreas de atuação. Enquanto vinculados ao Projeto também lhes foi proporcionado a participação em diferentes Eventos Científicos para divulgação dos resultados alcançados em suas atividades como monitores, o que certamente contribuiu para o compartilhamento de ideias e ampliação de seus conhecimentos.

Algumas das atividades desenvolvidas estão descritas nos capítulos e esperamos que sirvam de estímulo para o enriquecimento do processo ensino-aprendizagem, podendo ser replicadas ou até mesmo subsidiar novos Projetos de Extensão.

Bruna Gardenal Fina Camila Aoki 


\section{SUMÁRIO}

CAPÍTULO I - A EXTENSÃO UNIVERSITÁRIA COMO FERRAMENTA DE APRENDIZAGEM .10

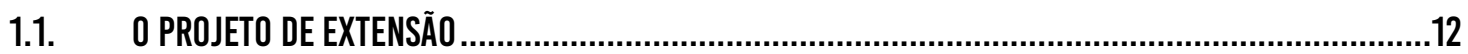

1.2. ATIVIDADES EXTERNAS DESENVOLVIDAS ………................................................................ 13

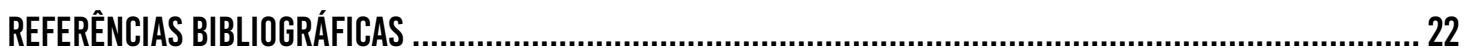

CAPÍTULO II - GEOGRAFIA: A EXTENSÃO COMO PRÁTICA INTERDISCIPLINAR PARA ALICERCE DO APRENDIZADO RELATO DE EXPERIÊNCIA

2.1. OS DESAFIOS DA CIÊNCIA GEOGRÁFICA NO PROJETO DE EXTENSÃO INTERDISCIPLINAR .....................24

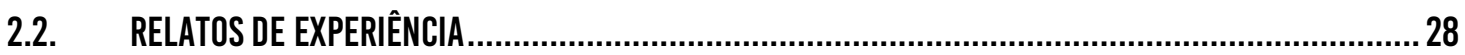

2.3. CONSIDERAÇ̃̃ES FINAIS ..............................................................................................

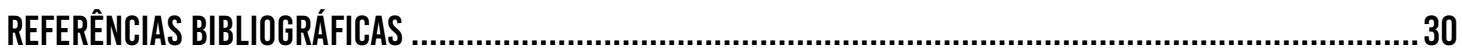

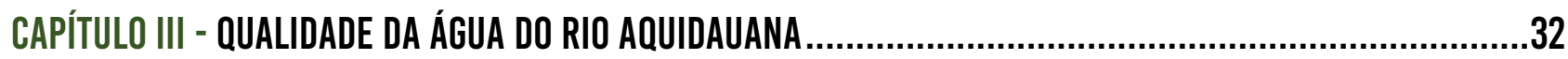

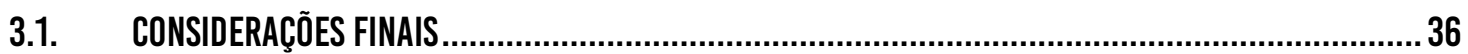

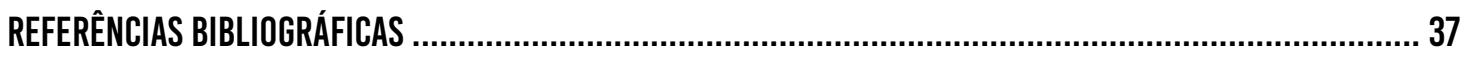

CAPÍTULO IV - EDUCAÇÃO AMBIENTAL PARA A CONSERVAÇÃO DA FAUNA SILVESTRE NO PANTANAL

4.1. ATIVIDADES DESENVOLVIDAS NO PROJETO .......................................................................... 39

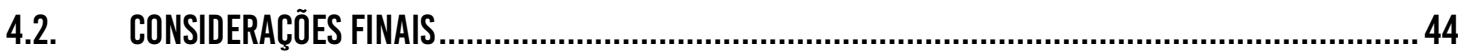

REFERÊNCIAS BIBLIOGRÁFICAS ............................................................................................ 44

CAPÍTULO V - A EXTENSÃO NO (RE)CONHECIMENTO DA FLORA DO CERRADO E PANTANAL ...........................47

5.1. ATIVIDADES DESENVOLVIDAS ........................................................................................... 48

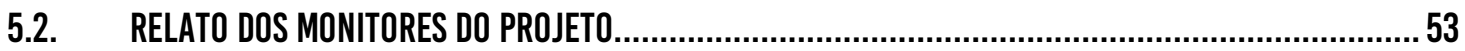

5.3. CONSIDERAÇ0̃ES FINAIS...............................................................................................

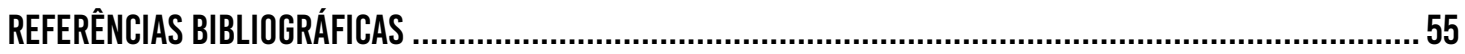

CAPÍTULO VI - EDUCAÇÃO AMBIENTAL NA FORMAÇÃO DO CIDADÃO ECOLÓGICO ......................................57

6.1. ATIVIDADES DE EDUCAÇÃO AMBIENTAL DESENVOLVIDAS .........................................................59

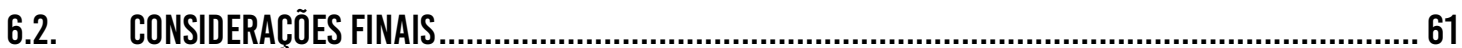


REFERÊNCIAS BIBLIOGRÁFICAS.

CAPÍTULO VII - RELATOS DE EXPERIÊNCIAS COM A DISCIPLINA DE CIÊNCIAS.

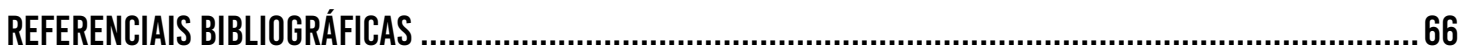




\section{CAPITULOI}

\section{A EXTENSÃO UNIVERSITÁRIA COMO FERRAMENTA DE APRENDIZAGEM}

Bruna Gardenal Fina ${ }^{1}$

Camila Aoki 1,2,3

1. Docente do Curso de Ciências Biológicas, Universidade Federal de Mato Grosso do Sul, Campus de Aquidauana, Rua Oscar Trindade de Barros, 740, Bairro da Serraria, Aquidauana, MS, Brasil, 79200-000.

2. Docente do Programa de Pós-Graduação em Recursos Naturais, Faculdade de Engenharias, Arquitetura e Urbanismo e Geografia (FAENG), Av. Costa e Silva, s/n - Cidade Universitária, Campo Grande, MS, Brasil, 79070-900.

3. Docente do Programa de Pós-Graduação em Biologia Vegetal, Instituto de Biociências (INBIO), Av. Costa e Silva, s/n - Bairro Universitário, Campo Grande, MS, Brasil, 79070-900.

Os Parâmetros Curriculares Nacionais (PCNs) definem Ciências como uma elaboração humana para a compreensão do mundo (BRASIL, 1998). Seus procedimentos podem estimular uma postura reflexiva e investigativa sobre os fenômenos da natureza e de como a sociedade nela intervém, utilizando seus recursos e criando uma nova realidade social e tecnológica (MALAFAIA; RODRIGUES, 2008).

Nas escolas, os livros didáticos representam muitas vezes o único recurso didático disponível para o desenvolvimento das aulas de Ciências. Embora seja um recurso de importância fundamental, geralmente apresenta uma abordagem linear de informações e fragmentação do conhecimento, os quais limitam a ação interdisciplinar (VASCONCELOS; SOUTO, 2003).

A abordagem docente tradicional normalmente orienta a seleção de conteúdos em atividades embasadas na memorização, com raras oportunidades de contextualização dos mesmos. A aplicação de questionários e lista de exercícios são exemplos comuns dessa prática. Assim, formam-se indivíduos treinados a repetir conceitos, aplicar fórmulas, mas incapazes de relacionar esse conhecimento a seu cotidiano (MALAFAIA; RODRIGUES, 2008).

Segundo Santos (2017), nas últimas décadas o conceito de aprendizagem teve que tornarse mais dinâmico, e aprender passou a ser exigência instrumental, relativa, e não mais uma 
capacidade determinante, estanque e absoluta. Diz ainda que toda aprendizagem só é de fato significativa, caso se insira de forma ativa na realidade.

Entende-se como aprendizagem significativa aquela que se fundamenta em um modelo dinâmico, onde o aluno é levado em conta, com todos os seus saberes e interconexões mentais. Nesse contexto, as atividades experimentais, desenvolvidas sob a orientação de professores, a partir de questões investigativas que tenham consonância com o cotidiano dos alunos, devem fornecer subsídios para a aplicação da teoria na resolução dos problemas e dar significado à aprendizagem da Ciência (GONZÁLES, 1992).

Dentre essas práticas pode-se citar a contextualização dos conteúdos com o cotidiano dos alunos; a adoção do método investigativo; o desenvolvimento de atividades práticas laboratoriais; o uso de espaços alternativos para o processo de ensino, entre outras. Entretanto, o uso dessas práticas dialógicas, investigativas e interdisciplinares ainda é um desafio para muitos professores.

Nesse sentido, a Extensão Universitária, que parte da premissa da troca de saberes entre a academia e a comunidade, tem importante papel na ação transformadora da realidade local. Assim, entendendo a necessidade de melhoria na qualidade do processo ensino-aprendizagem, a partir de Edital CAPES - Programa Novos Talentos e apoio da UFMS/CPAQ, elaborou-se um Projeto de Extensão que buscava a capacitação de Professores da Educação Básica, articulando práticas integrativas e relacionadas ao cotidiano dos alunos ao processo de ensino tradicional.

As atividades propostas visaram reunir professores de diferentes escolas e proporcionar um momento de reflexão acerca das metodologias utilizadas para o Ensino de Ciências, mostrando a inter-relação entre as diferentes áreas do saber e proporcionando a construção conjunta de abordagens interdisciplinares para alguns temas, principalmente relacionados à educação ambiental.

O Projeto de Extensão envolveu duas Escolas Públicas e contou com a participação direta de professores das áreas de Ciências, Geografia e Português, juntamente com seus alunos do 6oㅜ e 7ํano do ensino fundamental. Teve como principal objetivo facilitar o ensino de Ciências e foi desenvolvido ao longo de dois anos (2013-2015).

O tema gerador das discussões foi o rio Aquidauana, conhecido por todos os integrantes do Projeto, uma vez que representa o principal rio de drenagem do município, sendo um local agradável para visitação e que possibilita diversas reflexões acerca do ambiente que nos rodeia. Ao enfocar o rio Aquidauana foi possível trabalhar diversas temáticas usando o conhecimento já 
adquirido de alunos/professores e suas diferentes interpretações como estímulo à participação e contribuição ao Projeto.

Assim, o projeto incentivou os participantes a atuarem de forma conjunta, participativa e colaborativa. Incluiu a realização de atividades externas como descida do rio de barco; visitas monitoradas a Museus, Empresas e Centros de Pesquisa; atividades em laboratórios; além daquelas realizadas semanalmente em sala de aula (nas escolas de EB e na Universidade), contando sempre com o auxílio dos professores da Educação Básica e monitores do CPAQ. As atividades incluíram temas e discussões a respeito da proteção e restauração de ambientes, sobre a biodiversidade, qualidade da água, conservação de energia, reciclagem, qualidade do ar, aspectos da paisagem, da ecologia, além de produção textual.

Ressalta-se a importância, durante o desenvolvimento do Projeto, do comprometimento de todos os atores para que os frutos fossem colhidos. É imprescindível nas atividades de Extensão a participação coletiva, o respeito, a cumplicidade e a troca de experiência em todas as ações desenvolvidas.

\subsection{O PROJETO DE EXTENSÃO}

O Projeto agregou sete professores, sendo seis docentes de nível superior de diferentes áreas (Ciências Biológicas, Geografia, Turismo, Pedagogia e Letras) e uma professora EBTT de Geografia do IFMS local. Participaram também, direta e intensamente, cerca de 20 monitores (entre graduandos e pós-graduandos), seis professores da Educação Básica, além de 25 alunos do ensino fundamental.

As atividades foram desenvolvidas por meio de encontros semanais na Universidade Federal de Mato Grosso do Sul (UFMS), campus de Aquidauana, no período de 2013 a 2015, onde foram realizadas palestras, oficinas, aulas práticas em laboratório e na sala de informática. Também foram realizadas atividades de campo e viagens técnicas, visando oportunizar um processo de ensino-aprendizagem diferenciado, com abordagem integradora dos diversos conteúdo do ensino Fundamental.

Nos encontros semanais foram abordados temas como a Conservação dos recursos naturais; Educação ambiental; Leitura e Produção de textos; Caracterização dos biomas Cerrado e Pantanal; Diversidade da fauna e flora regional; Qualidade da água; Conceitos de Bacias hidrográficas; Consequências das atividades antrópicas; Poluição, além da realização de 
Atividades práticas laboratoriais; Atividades interdisciplinares e Exposição de trabalhos pelos alunos.

Como atividades externas foram realizadas: Descida de barco do rio Aquidauana; Visita à Empresa de Saneamento do Estado - Sanesul; Visita ao Centro de Reabilitação de Animais Silvestres (CRAS) e ao Museu Dom Bosco em Campo Grande-MS; Visita à Base de Pesquisa do Pantanal em Miranda-MS; Visita ao Projeto "Nascente Azul” e Aquário Municipal em Bonito/MS; Visita ao Museu de História do Pantanal e Museu Estação Ciência da Fundação Boticário em Corumbá-MS.

Todas as ações realizadas tiveram como prioridade a integração entre os participantes, a aproximação das escolas de Educação Básica com a Universidade e o enfoque interdisciplinar, adotando a metodologia da pesquisa-ação para o desenvolvimento do Projeto.

Muitos foram os resultados positivos desde o início, como a confecção do slogan pelos próprios alunos; a análise da qualidade da água coletada na descida de barco do rio Aquidauana em laboratório; confecção de maquete das áreas de risco do rio Aquidauana; confecção de moldes de pegadas de animais silvestres; aprendizagem de técnicas de coleta e herborização das plantas; uso de novas tecnologias; apresentação do Projeto para a comunidade local em diferentes oportunidades (Feira de Ciências nas escolas, Semana do Meio Ambiente na UFMS/CPAQ, Feira da Estação Pantaneira, Dia Mundial da Água...), entre inúmeras outras ações.

Assim, podemos dizer que nossos objetivos foram concretizados, com muito empenho de todos os participantes, vez que pudemos incentivar a pesquisa e estreitar o relacionamento de alunos e professores da Educação Básica com a Universidade Federal, promovendo maior motivação para a continuidade de seus estudos; incentivar o uso de espaços alternativos no processo de aprendizagem; estimular a prática interdisciplinar; abordar questões socioambientais evidenciando a responsabilidade de todos na manutenção da qualidade e diversidade ambiental, além de aumentar a autoestima de muitos estudantes/professores, que, através do Projeto de Extensão, foram reconhecidos e valorizados em suas ações cotidianas.

\subsection{ATIVIDADES EXTERNAS DESENVOLVIDAS}

As atividades externas favorecem a interdisciplinaridade uma vez que diferentes assuntos podem ser trabalhados simultaneamente e de forma contextualizada, permitindo assim uma visão crítica da realidade. Ainda favorece a cooperação, a criatividade, o desenvolvimento de atividades em grupo, a responsabilidade e a autonomia dos estudantes. Assim, no decorrer 
do Projeto, além de atividades habituais em sala de aula, algumas atividades extra-classe foram oportunizadas, como segue:

\subsubsection{DESCIDA DE BARCO NO RIO AQUIDAUANA}

Essa foi a primeira atividade realizada e teve como objetivo a sensibilização inicial de todos os participantes do Projeto de Extensão acerca da qualidade ambiental do rio, visando conscientizar sobre as ações antrópicas e sua interferência no ambiente natural (Figura 1).

Figura 1. Descida no rio Aquidauana de barco. Aquidauana/MS.
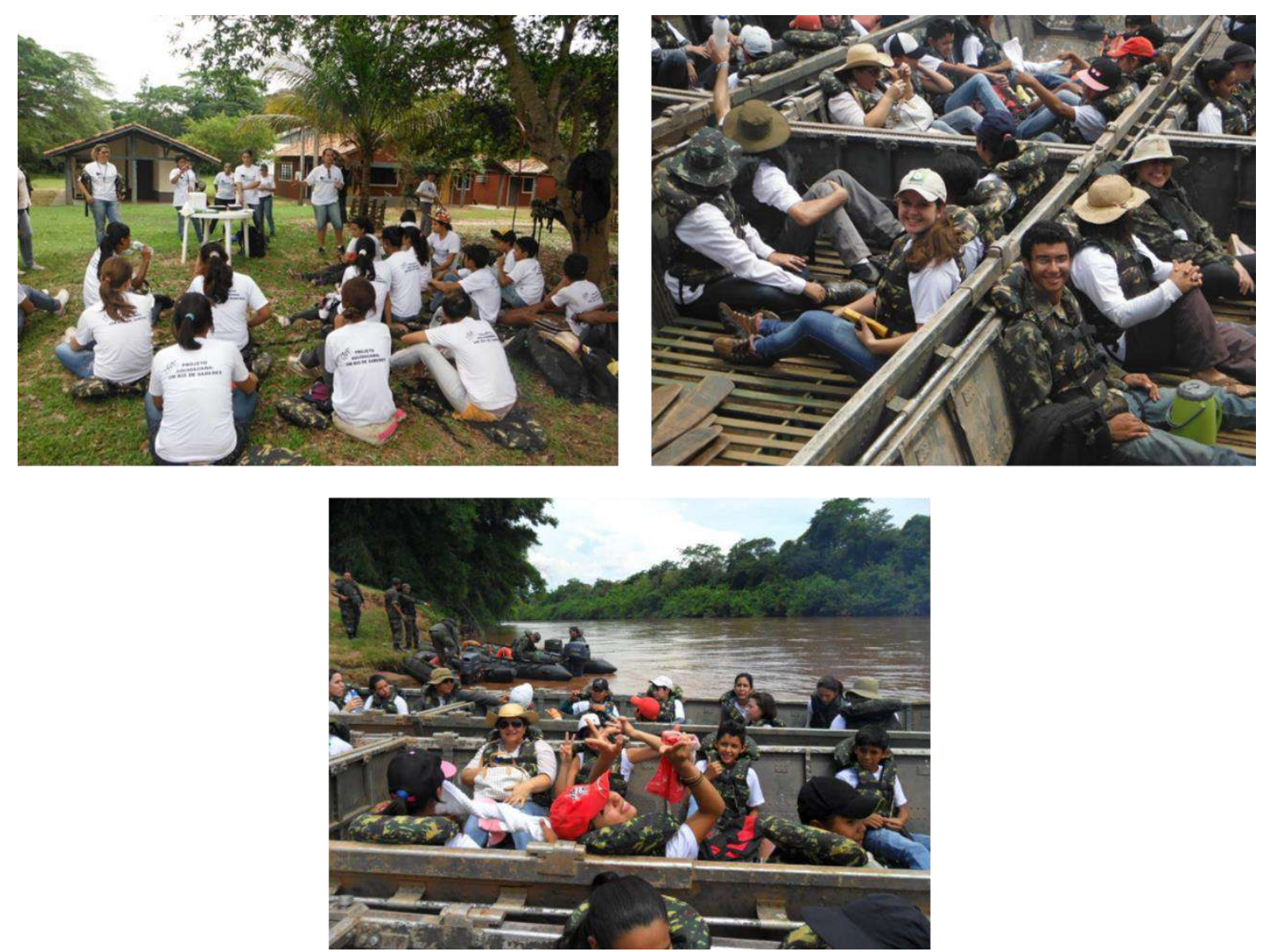

Foram trabalhadas posteriormente em sala de aula e laboratórios a caracterização da Bacia do rio Aquidauana e sua importância para população local e para o Pantanal; a caracterização da qualidade da água (química, física e microbiológica); caracterização da fauna e flora local, entre outros aspectos. 


\subsubsection{VISITA A EMPRESA DE ABASTECIMENTO DE ÁGUA E ESGOTO}

Essa atividade teve como objetivo a discussão sobre a importância dos recursos hídricos na manutenção da biodiversidade e qualidade de vida da população.

Foram demonstradas in loco todas as etapas necessárias para o abastecimento e tratamento da água e do esgoto (Figura 2). Posteriormente várias outras questões pertinentes foram abordadas como a crise hídrica, qualidade da água, poluição dos recursos hídricos, entre outros.

Figura 2. Visita à Empresa de Saneamento de água e esgoto de Aquidauana/MS.
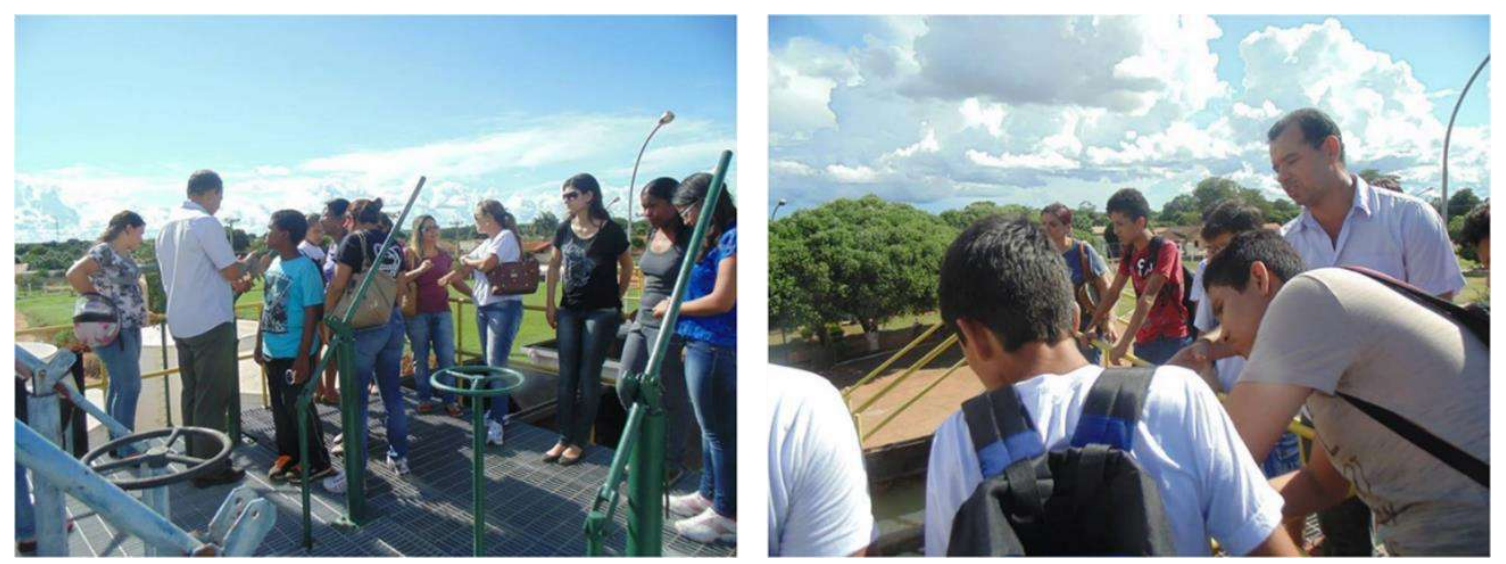

\subsubsection{VISITA AO CENTRO DE REABILITACÇÃO DE ANIMAIS SILVESTRES}

Essa atividade teve como objetivo proporcionar o (re)conhecimento de diversos animais silvestres e sua atual condição na natureza.

Foram trabalhadas posteriormente em sala de aula e em outras atividades externas questões como caça, domesticação, atropelamentos, comércio ilegal de animais silvestres, biopirataria, uso de plantas madeireiras/outras, e a forma como todas essas atividades interferem na biodiversidade local/global (Figura 3). 
Figura 3. Visita ao Centro de Reabilitação de Animais Silvestres e Parque Estadual do Prosa Campo Grande/MS.
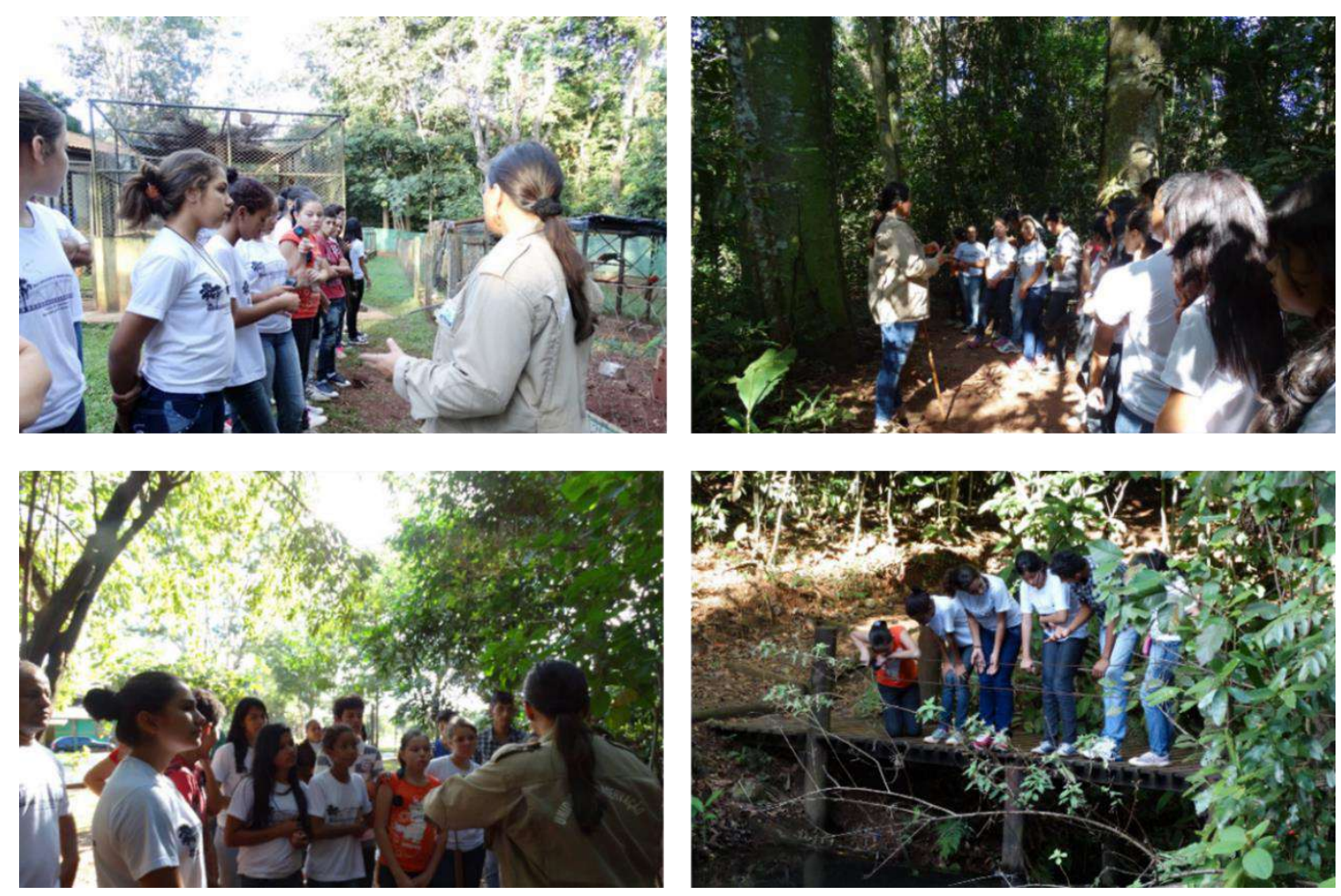

\subsubsection{VISITA AO MUSEU DOM BOSCO}

Essa atividade teve como objetivo conhecer diferentes aspectos da história, cultura e diversidade regional, incluindo excelente acervo sobre a cultura indígena local. Foram trabalhados aspectos da geologia, arqueologia, origem e formação do Pantanal, bem como das diferentes etnias existentes no Estado e sua relação com o ambiente, além da fauna e flora regional (Figura 4).

O Museu conta com acervo temporário que abrange a área de ciências naturais, onde há vários animais taxidermizados que são representativos da fauna do Cerrado e Pantanal, além de fósseis e coleções entomológicas, que abrigam invertebrados de diversas localidades do mundo. 
Figura 4. Visita ao Museu Dom Bosco, Campo Grande/MS.
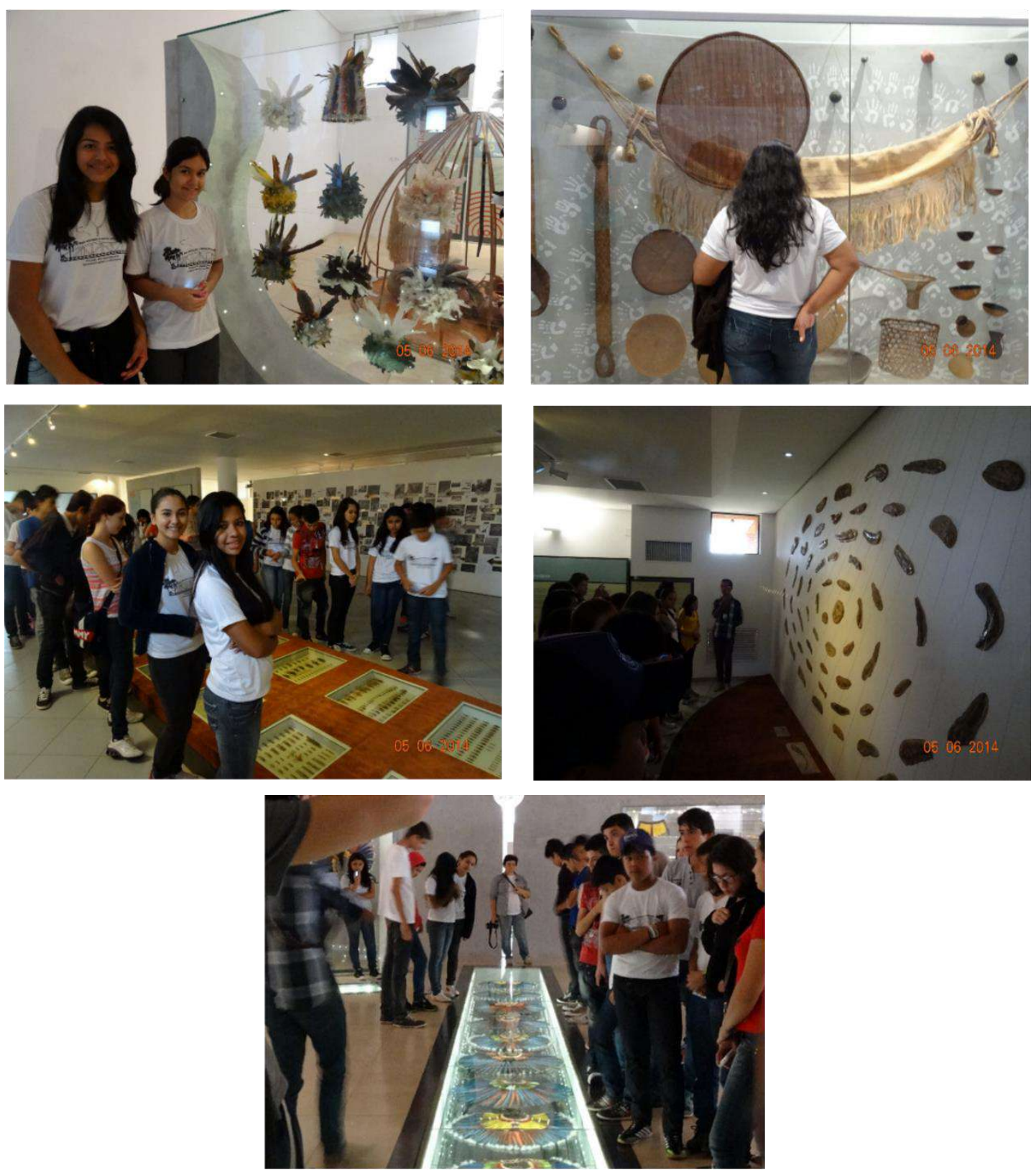

\subsubsection{VIAGEM A BASE DE ESTUDOS DO PANTANAL- MIRANDA/MS}

Esta atividade teve como principal objetivo a realização de atividades práticas de caráter investigativo nas diferentes áreas abordadas no Projeto. Foram trabalhados aspectos da interdependência das Bacias hidrográficas (fluxo de cheias/secas no Pantanal); das interrelações entre os diferentes organismos e principalmente da integração das diferentes áreas do saber. Os alunos tiveram contato com metodologias de pesquisa utilizadas em diferentes áreas da botânica e zoologia, como coleta de material e confecção de exsicatas, coleta de insetos 
(abelhas, borboletas, libélulas), identificação de rastros e uso de armadilhas de pegada (Figura $5)$.

Figura 5. Visita à Base de Estudos do Pantanal, Miranda/MS.
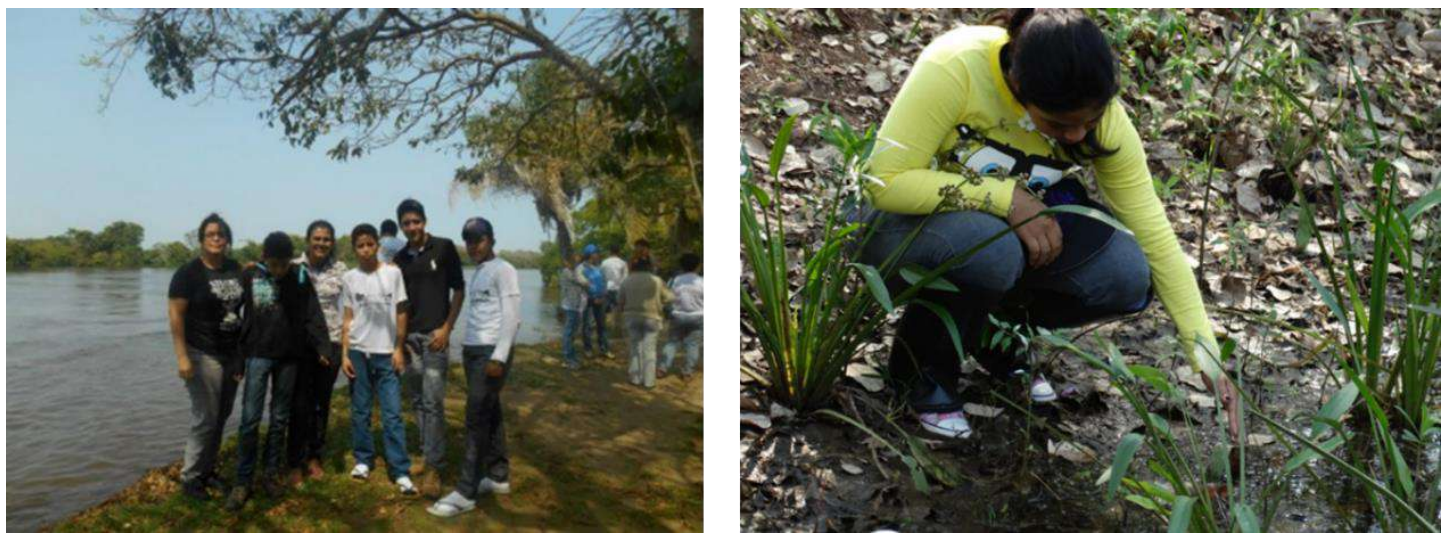

\subsubsection{VIAGEM A BONITO-MS}

Essa atividade teve como objetivo proporcionar a visitação de um dos lugares mais conhecidos do Brasil e do Estado de Mato Grosso do Sul com o intuito de despertar o "pertencimento" em cada um dos participantes do Projeto, vez que estamos "tão próximos" (cerca de $200 \mathrm{~km}$ ) e ao mesmo tempo "tão longe" (por questões econômicas, principalmente) desse paraíso (Figura 6).

Nessa viagem foram realizadas visitas ao Aquário Municipal e Nascente Azul. Posteriormente foram trabalhados aspectos da biodiversidade, da inter-relação entre seus diferentes componentes, da fragilidade dos ambientes e da biodiversidade, entre outros. 
Figura 6. Atividades desenvolvidas em Bonito/MS. Visita ao Aquário municipal e Nascente Azul.
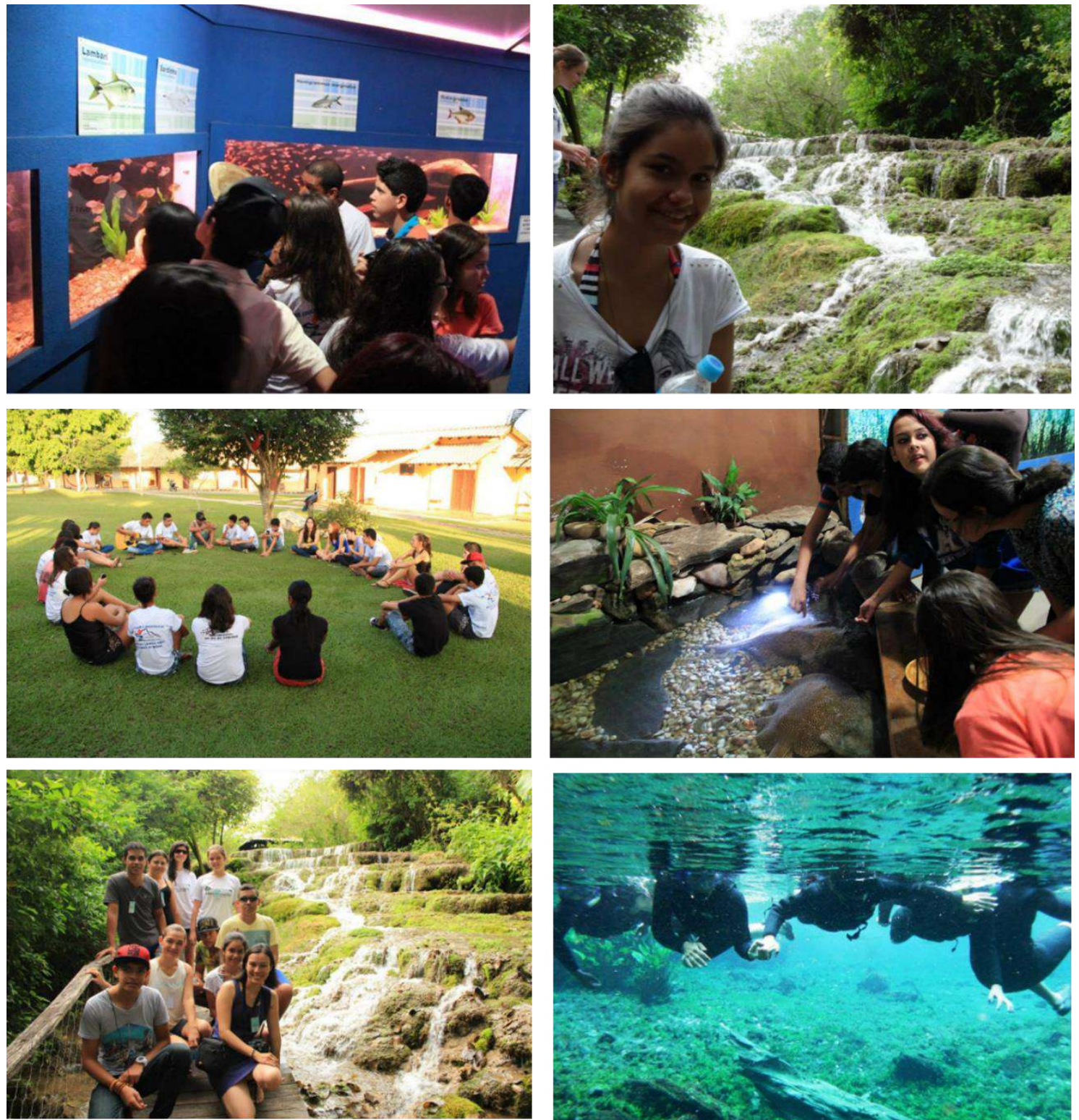

\subsubsection{VISITA AO MUSEU DE HISTÓRIA DO PANTANAL E ESTAÇ̃̃O NATUREZA PANTANAL - CORUMBÁ/MS}

Esta atividade teve como objetivo o contato com a história, cultura e a natureza pantaneira, desde a formação do complexo Pantanal, sua biodiversidade e suas peculiaridades culturais.

O Museu expõe suas peças arqueológicas de forma que os alunos conheçam o homem que habitava o Pantanal há oito mil anos até o momento da chegada do colonizador (Figura 7). Parte do Museu é bem dinâmico e interativo despertando a curiosidade e participação dos alunos que puderam perceber a paisagem pantaneira durante a seca e as cheias mediante efeitos visuais e sonoros do ambiente e dos animais. 
Também tiveram a oportunidade de conhecer por dentro uma réplica do trem que percorria a estrada de ferro Noroeste do Brasil, de Corumbá a São Paulo. Pelas janelas do trem puderam admirar a paisagem do ecossistema pantaneiro (Figuras 8).

Por meio dos conteúdos ligados à arqueologia, etnologia, história e antropologia, os alunos puderam entender a história de ocupação no Pantanal, assim como, apreciar a diversidade cultural, artística e ecológica, entendendo o espaço museal como fortalecedor de identidade e cidadania das pessoas que ali vivem.

Posteriormente à visitação, foram realizadas abordagens sobre a história, cultura regional e a conservação do Pantanal, entre outros aspectos.

Figura 7. Aspectos da cultura e história do homem pantaneiro. Museu de história do Pantanal, Corumbá/MS.
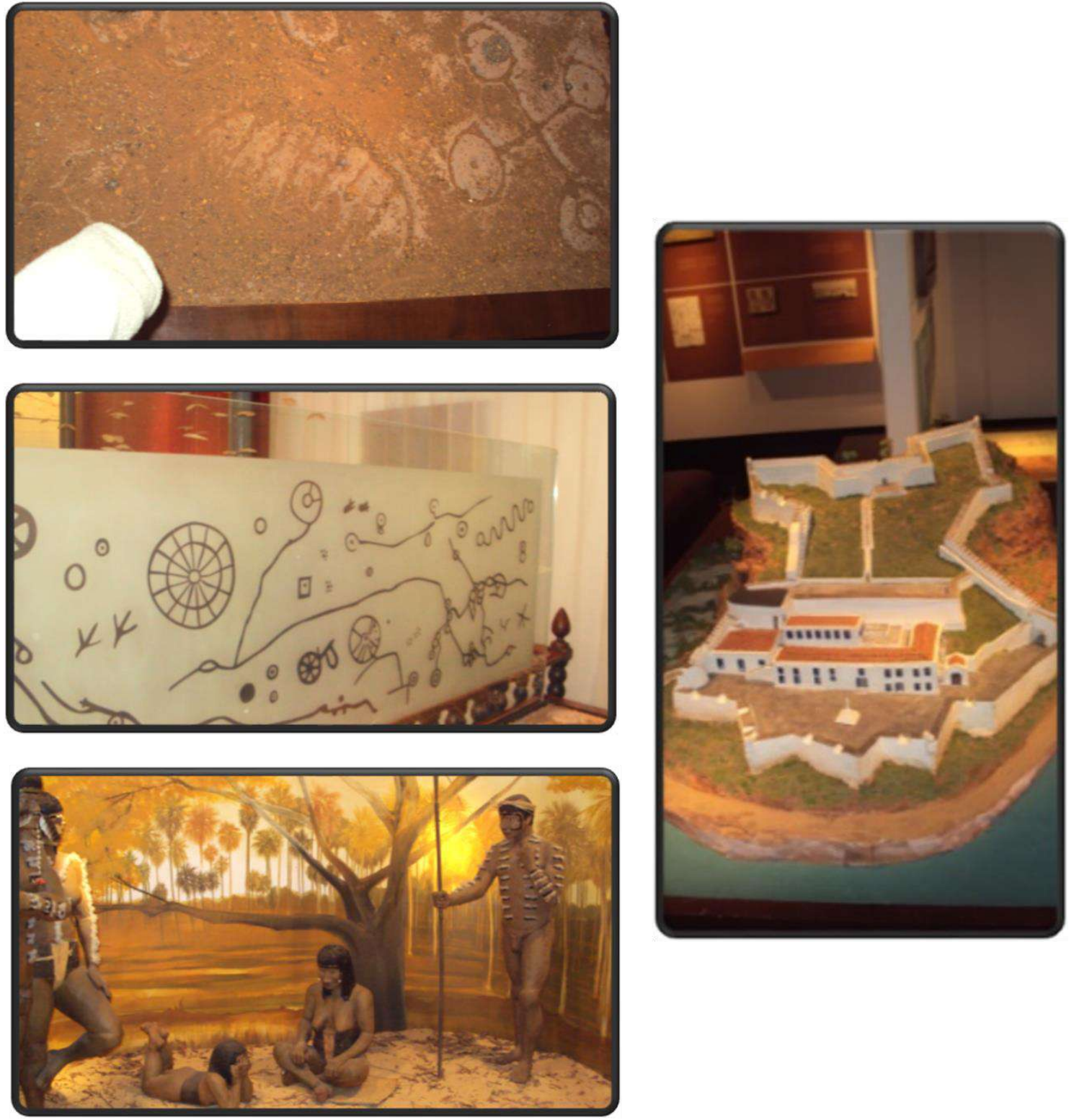
Figura 8. Palestra e visita ao Museu de história do Pantanal, Corumbá/MS.
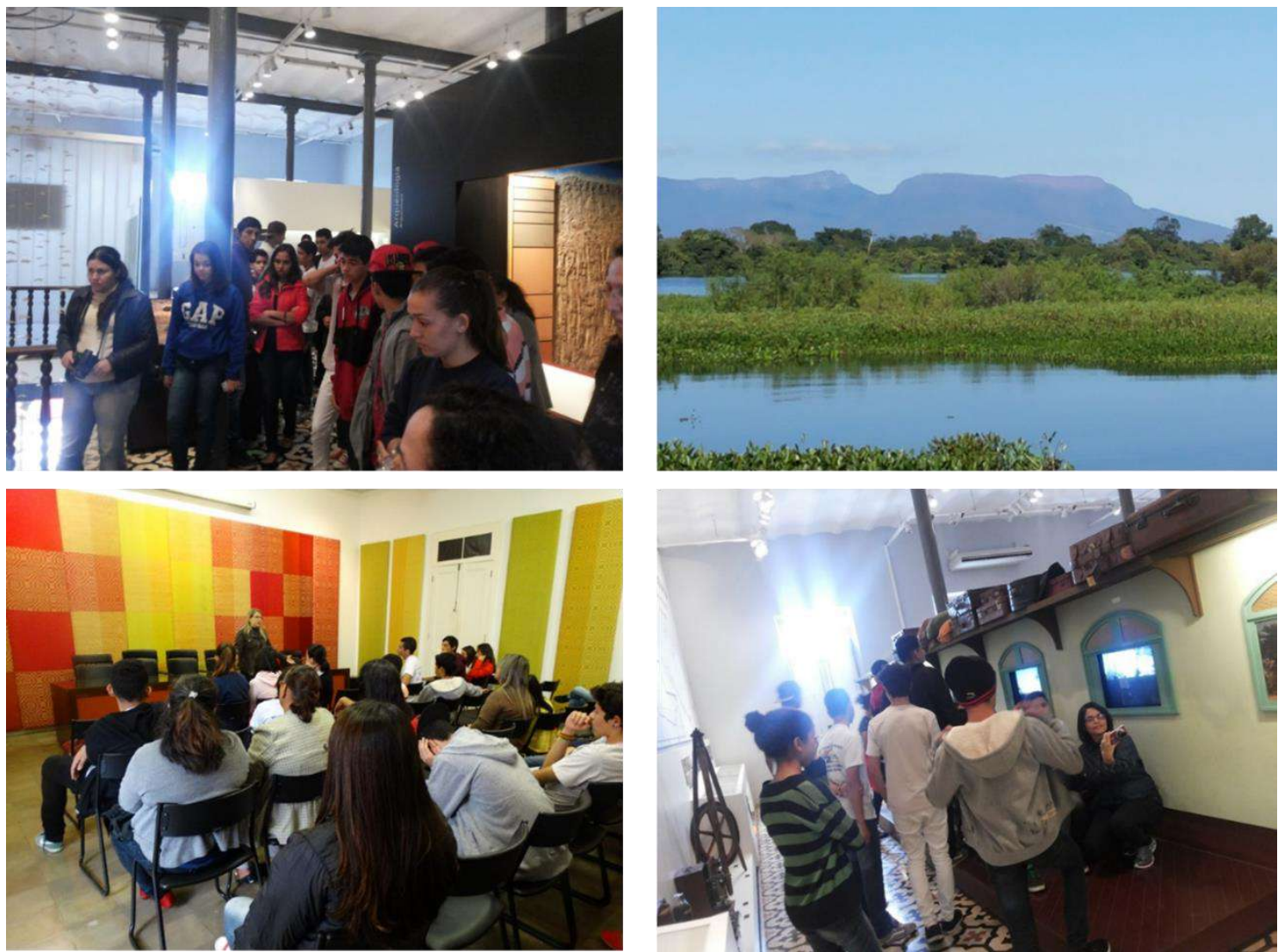

O encerramento das atividades externas no município de Corumbá-MS teve como principal intenção a conexão de todo o aprendizado ao longo do Projeto em sua visão macro, uma vez que o rio Paraguai representa o elo maior das três bacias hidrográficas estudadas. Partimos do rio Aquidauana até o rio Miranda (Base de Estudos do Pantanal) e deste para o rio Paraguai, num fluxo contínuo de troca de saberes e aprendizagens.

Durante o trajeto para Corumbá os alunos puderam perceber a modificação do relevo e da paisagem. A vegetação, constituída principalmente por cerrado em Aquidauana, vai se modificando rumo às planícies pantaneiras em Corumbá. Ressalta-se ainda que Corumbá é uma das cidades mais antigas do Estado e além das belezas naturais, possui importante acervo histórico-cultural.

Importante lembrar que o desenvolvimento de um projeto de extensão com tantas atividades e atores envolvidos só foi possível devido a proposta do edital do Programa Novos Talentos da Coordenação de Aperfeiçoamento de Pessoal de Nível Superior - CAPES/Brasil. Considerando todos os objetivos alcançados e a experiência proporcionada aos alunos e professores, julgamos premente a abertura de editais como este para a melhoria do processo educacional no Brasil. 


\section{REFERÊNCIAS BIBLIOGRÁFICAS}

BRASIL, Ministério da Educação e do Desporto, Secretaria de Educação Fundamental. Parâmetros Curriculares Nacionais. Brasília: Ministério da Educação e do Desporto, 1998, 436p.

GONZÁLES, E. M. Qué hay que renovar em los trabajos práticos? In: Enseñanza de las Ciências, v. 10, p. 206-11. 1992.

MALAFAIA, G.; RODRIGUES, A.S.L. Uma reflexão sobre o ensino de ciências no nível fundamental da educação. Ciência e Ensino, v.2, n. 2, p. 1-9, 2008.

MOREIRA, M.A. Aprendizagem significativa. Brasília: Ed. UNB, 1999. 129p.

NARDI, R.(org). Educação em ciências: da pesquisa à prática docente. São Paulo: Escrituras Editora, 2001.

SANTOS, J. C. F. 0 desafio de promover a aprendizagem significativa. Disponível em: http://www.juliofurtado.com.br/textodesafio.pdf. Acesso em maio 2020.

VASCONCELOS, S.D.; SOUTO, E. O livro didático no ensino fundamental - proposta para análise do conteúdo zoológico. Revista Ciência e Educação, v. 9, n. 1, p. 93-104, 2003.

WEISZ, T. 0 diálogo entre o ensino e a aprendizagem. Ed. Ática, 1999. 133p. 


\section{CAPITULO II}

\section{GEOGRAFIA: A EXTENSÃO COMO PRÁTICA INTERDISCIPLINAR PARA ALICERCE DO APRENDIZADO - RELATO DE EXPERIÊNCIA}

Lucy Ribeiro Ayach ${ }^{1}$ Hilda Ribeiro Romero ${ }^{2}$ Enzo Rufino Leite ${ }^{3}$

1. Docente do Curso de Geografia e Coordenadora do Curso de Pós-graduação Mestrado em Geografia na Universidade Federal de Mato Grosso do Sul, Campus de Aquidauana, Rua Oscar Trindade de Barros, 740, Bairro da Serraria, Aquidauana, MS, Brasil, 79200-000.

2. Diretora-Geral e Docente do IFMS, Campus de Aquidauana, Rua José Tadao Arima, 222, Bairro Ycaraí, Aquidauana-MS, Brasil, 79.200-000

3. Graduado em Geografia, Universidade Federal de Mato Grosso do Sul, Campus de Aquidauana. Rua Oscar Trindade de Barros, 740, Bairro da Serraria, Aquidauana, MS, Brasil, CEP: 79200-000.

O Projeto de Extensão "Aquidauana: Um rio de saberes desaguando no Pantanal” foi desenvolvido com o apoio da CAPES - Coordenação de Aperfeiçoamento de Pessoal de Nível Superior, por meio do Programa Novos Talentos, no período de 2013 a 2015 no município de Aquidauana, estado de Mato Grosso do Sul. Foi realizado pela Universidade Federal de Mato Grosso do Sul - UFMS, Campus de Aquidauana-MS, em parceria com o Instituto Federal de Mato Grosso do Sul - IFMS, Unidade de Aquidauana.

O Projeto de extensão teve em sua essência a interdisciplinaridade, incluindo a participação dos cursos da UFMS de Ciências Biológicas, Geografia, Letras e Pedagogia, envolvendo professores e acadêmicos dos referidos cursos, bem como a participação de Professores do IFMS.

Tendo em vista o objetivo do programa Novos Talentos de contribuir com a Educação Básica por meio de projetos da Universidade, o projeto foi desenvolvido com a parceria de duas Escolas da Rede Pública do Estado de Mato Grosso do Sul, localizadas na cidade de Aquidauana: E.E. Antônio Salústio Areias e E.E. Marechal Deodoro da Fonseca, com a participação de 
professores das áreas de Geografia, Biologia, Português e Matemática e alunos da Educação Básica das referidas escolas.

As atividades desenvolvidas no referido projeto de extensão foram aulas teóricas, palestras, atividades práticas de campo e em laboratórios, além de oficinas de produção de texto, de forma interdisciplinar, realizadas na Universidade, nas escolas e em viagens de campo a diferentes localidades no estado. Todas as atividades foram acompanhadas por grupos alternados, previamente organizados, de professores da Universidade e Instituto Federal, professores das Escolas e alunos da Universidade dos diferentes cursos como monitores.

\subsection{OS DESAFIOS DA CIÊNCIA GEOGRÁFICA NO PROJETO DE EXTENSÃO INTERDISCIPLINAR}

O tema central do projeto foi a bacia hidrográfica do Rio Aquidauana que compõe a bacia hidrográfica do Rio Miranda e Rio Paraguai, portanto, importante componente da planície do Pantanal Sul-matogrosssense. As atividades envolveram o conhecimento e debates sobre a conservação dos recursos naturais na região pantaneira, a importância da qualidade da água, do funcionamento do sistema ambiental, da fauna, flora, os impactos ambientais e o papel da sociedade nesse sistema. As atividades contemplaram diferentes enfoques por meio do tema gerador e proporcionaram, por meio de roteiros pedagógicos pré-estabelecidos, discussões e resultados expressos de forma verbal e/ou escrita, contemplando uma análise interdisciplinar (Figura 1). 
Figura 1. Atividades sobre saneamento e apresentação da maquete das áreas de risco do rio Aquidauana/MS.
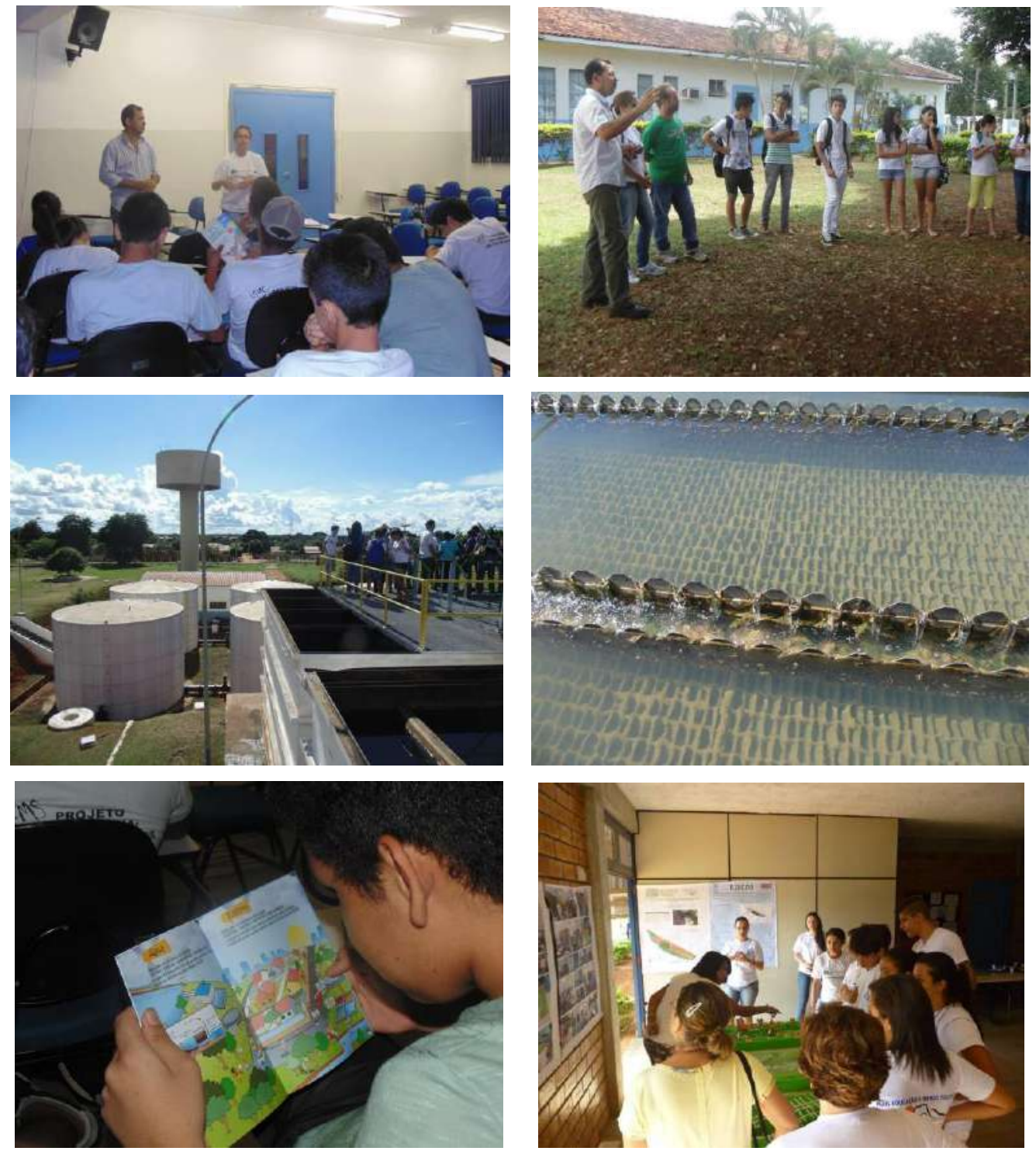

Não é objeto da presente análise, abordar a profundidade que o conceito de interdisciplinaridade exige, porém deve-se atentar para a abrangência desse conceito.

A necessidade da interdisciplinaridade na produção e na socialização do conhecimento no campo educativo vem sendo discutida por vários autores, principalmente por aqueles que pesquisam as teorias curriculares e as epistemologias pedagógicas. De modo geral, a literatura sobre esse tema mostra que existe pelo menos uma posição consensual quanto ao sentido e à finalidade da interdisciplinaridade: ela busca responder à necessidade de superação da visão fragmentada nos processos de produção e socialização do conhecimento (THIESEN, 2008 p. 545).

No contexto de desenvolvimento das atividades de forma interdisciplinar, a ciência geográfica, intrinsecamente, possui uma característica que exige essa visão interdisciplinar, 
desafiando professores a propor um estudo e reflexão da realidade vivida não dissociada da informação científica.

Os desafios da ciência geográfica impõem ao professor/pesquisador, um olhar sistêmico para a realidade, capaz de interpretá-la a partir da interconexão entre territórios vividos (lugares) e territórios globalizados (AYACH; BATISTA; FARIAS, 2020 p. 116.).

Em sala de aula, o professor de Geografia do ensino fundamental é desafiado a superar o seu fazer pedagógico, tendo por base o PCN (1998. p.26), onde destaca que um dos objetivos do ensino da Geografia é levar o estudante a compreender as relações entre o processo na formação das sociedades humanas e funcionamento da natureza por meio da leitura do lugar, do território, a partir de sua paisagem. Uma das alternativas para atingir tais objetivos, é o desenvolvimento de projetos interdisciplinares em parcerias com as Universidades e Institutos Federais.

O cotidiano em sala de aula e as rotinas escolares em sua maioria não proporcionam aos professores o desenvolvimento de atividades práticas aos estudantes, tanto por falta de recursos quanto de estruturas administrativas e políticas pedagógicas que apoiam tais práticas. 0 desafio não está somente em levar a prática pedagógica do ensino na Geografia à sala de aula, mas também formar professores para atuarem no ensino da Geografia com uma base teórica e práticas interdisciplinares.

As atividades universitárias extensionistas cumprem essa finalidade, pois conciliam o conhecimento teórico, a troca de experiência com quem já atua em sala de aula e a convivência com crianças e jovens de realidades diferenciadas, numa junção de perspectivas, desafios e saberes.

Se na própria universidade existe esse desafio, na formação básica essa busca se torna ainda maior, mas sobretudo com maiores possibilidades de alternativas aos alunos, dada a faixa etária de idade caracterizada pela demasiada curiosidade em conhecer e interpretar a realidade que o cerca.

\footnotetext{
Gonzalez Bernaldez (1981:04), referindo-se à paisagem visual ou percebida, afirma que a interpretação depende, também, da percepção do entorno, segundo as diferentes culturas e civilizações, sendo que o hábito da interpretação do entorno leva a uma consciência do nosso meio, que pode estar muito debilitada nas civilizações urbanas modernas.
}

Nesse sentido, as proposições do Projeto de Extensão "Aquidauana: Um rio de saberes desaguando no Pantanal" englobou atividades e ações específicas que promoveram o entendimento do sistema geográfico e, em especial, tendo a obrigatoriedade de "enxergar a 
geografia" nas demais ciências, minimizando o acentuado abismo ainda existente no ensino de geografia da educação básica que separa a geografia física da geografia humana.

Outro aspecto bastante positivo no desenvolvimento do projeto foi trabalhar com o tema "água”, por meio dos estudos da bacia hidrográfica do rio Aquidauana, o qual corta a cidade com o mesmo nome, numa região de riquíssimos recursos naturais, proporcionando estudos interdisciplinares. Considerando que o tema de estudo (rio Aquidauana) possui um sentido de lugar para os alunos que vivem no município de Aquidauana, as atividades de conhecimento ou reconhecimento dessa paisagem conduzem a uma percepção diferenciada de sua realidade vivenciada pelos diferentes alunos e também dos monitores e professores participantes.

Segundo o autor Tuan, lugar é uma "pausa do movimento", onde "o sentimento relativo ao lugar enraíza-se ou não nas pessoas, com intensidades e significados que se alteram ao longo dos anos em expressões de afetividade que as levam a agir e a reagir sobre o meio ambiente circundante" (TUAN, 1983:153).

Neste sentido, para Guimarães (2002:125), as "maneiras de experienciar e interpretar as paisagens incorporam as interações imanentes ao significado do "vivido", derivando uma gama de percepções, valores, e atitudes diante de espaços e lugares[...]

0 rio Aquidauana drena o município e é um dos principais afluentes da Bacia Hidrográfica do rio Paraguai, com influência direta no regime de cheias do Pantanal. A bacia hidrográfica do rio Aquidauana possui 21.369,095 km², com reconhecida importância do ponto de vista ambiental, econômico e social. Sua nascente está localizada no município de São Gabriel do Oeste ao Norte do estado de Mato Grosso do Sul, com o médio curso na porção central do estado, passando pelos municípios de Corguinho, Rochedo, Terenos, Dois Irmãos do Buriti e baixo curso na orientação Centro-Oeste e Noroeste do estado nos municípios de Aquidauana, Anastácio e Miranda. Abrange o divisor das bacias do rio Paraguai e Paraná, drenado pelos afluentes da bacia do rio Paraguai. Destaca-se no contexto nacional e no Estado de Mato Grosso do Sul por apresentar três importantes unidades fisiográficas: o Planalto Maracaju-Campo Grande, a Depressão Pantaneira e a Planície do Pantanal Sul-Mato-Grossense, abrangendo parte dos biomas Cerrado e Pantanal.

O Pantanal, além de ser considerado Patrimônio Nacional assegurado pela da Constituição Federal (BRASIL, 1988), Patrimônio da Humanidade e Reserva da Biosfera pela UNESCO, é um ecossistema único no mundo que abrange o Brasil (70\%), Bolívia (20\%) e Paraguai (10\%). A porção brasileira é estimada em cerca de $138 \mathrm{mil} \mathrm{km}^{2}$, em que 35,36\% está no Mato Grosso e 64,64\% está no Mato Grosso do Sul (PERH, 2008). 
Assim esse percentual da área do Pantanal no Estado e a abrangência do município de Aquidauana $\left(17.087,021 \mathrm{~km}^{2}\right)$ que adentra ao Pantanal, revela a importância do entendimento desse ecossistema de incontáveis riquezas de recursos naturais, fauna e flora, incorporados ao espaço vivido de alunos e professores moradores de Aquidauana, aumentando as possibilidades de imersão durante as atividades de intepretação de forma interdisciplinar, constituindo-se em um ambiente propício ao exercício da prática pedagógica.

As atividades práticas, o estudo em grupo, as produções textuais e as análises vivenciadas pelos membros do projeto, proporcionaram uma mudança conceitual, tanto para os estudantes quanto para os estagiários, monitores e professores que fomos levados a reestruturar o que aprendemos e transmitimos em sala de aula. Aprendemos a ver, sentir e reconhecer o nosso lugar, como ressalta Gomes (2018. p.12) que a "Geografia é reconhecidamente uma disciplina visual, e sua história se apresenta como um grande e valioso campo de reflexão". A interação do aprender fazendo, vivenciando, interagindo com o meio onde vivemos, levou-nos a reconhecerse como ser integrante desse espaço geográfico.

O projeto proporcionou a análise de aspectos físicos, sociais, econômicos e ambientais, com a possibilidade de uma análise sobre a inter-relação dos fenômenos, considerando as diferentes escalas de análise do espaço geográfico.

\subsection{RELATOS DE EXPERIÊNCIA}

\subsubsection{VISÃO DE PARTICIPAÇÃO DAS PROFESSORAS DA UFMS E IFMS}

Como relato de experiência da atividade realizada, fica para nós, professoras da área de geografia da UFMS e IFMS, uma experiência que nos proporcionou a reflexão de dois pontos importantes: o primeiro foi a análise do acompanhamento das atividades realizadas pelos nossos estudantes, nos quais constatamos a importância do planejamento, das atividades práticas, do trabalho em grupo e da interdisciplinaridade. Em cada atividade concluída o aprendizado se ressignificou, deixou de ser adquirido em sala de aula por disciplinas desconectadas, passando a ser integrado, lógico, vivido e palpável. 0 rio Aquidauana e o Pantanal, de figuras estáticas dos livros didáticos de Geografia, passaram a ter movimento, vida, cheiro e encantamento.

O segundo ponto analisado foi a mudança no olhar do estudante e do seu comportamento. Iniciamos as atividades práticas com a descida pelo rio Aquidauana, com estudantes eufóricos, tomados pelo novo e pelo desconhecido. Muitas informações e perguntas complexas e de difícil 
compreensão, revelando um ambiente (rio) tão próximo e ao mesmo tempo distante e desconhecido.

Quando realizamos as atividades na Base de Pesquisa da UFMS no Passo da Lontra, Pantanal do rio Miranda, nossos estudantes se mostraram comprometidos com o meio ambiente, com a vida e com a ciência. 0 envolvimento, imersão e indagações realizadas pelos estudantes expressavam o quanto o projeto contribuiu para sua formação acadêmica e cidadã. 0 êxito do nosso projeto foi possível porque todos nós educadores nos desafiamos a fazer uma ação pedagógica interdisciplinar. 0 desafio foi vencido!

\subsubsection{VISÃO DE PARTICIPAÇÃO DO ACADÊMICO DA UFMS}

Primeiramente me senti grato e reconhecido pela coordenação e professores por ter a oportunidade de participar como monitor de um Projeto de Extensão que se tornou um divisor de águas na minha formação em Geografia-Licenciatura.

O projeto me proporcionou em primeira mão o contato direto com os alunos já no segundo ano de minha formação, contato este que teria apenas no final do curso. Esse contato me permitiu vivenciar relações com os alunos, dentro e fora das salas de aula, nos seminários, projetos e visitas a outros locais, sentindo-me responsável pelos mesmos e pelo compartilhamento de conhecimentos, fazendo com que tivesse a certeza do caminho a seguir.

A interdisciplinaridade do projeto me permitiu ainda o conhecimento de vários profissionais e principalmente professores de outras disciplinas comprometidos com o processo de ensino /aprendizagem, que em todo projeto mostraram verdadeiros mestres do saber, desde o acolhimento até a integração ao grupo.

As visitas aos diversos locais proporcionaram a todos nós a importância da realização de atividades fora das salas de aula, levando o aluno a ter contato direto com conteúdo visto apenas nos livros didáticos, seja realizando pesquisas, ou outras atividades práticas onde o aluno deixa de ser "objeto", passando a ser "sujeito", tornando-se participante na busca pelo conhecimento, conforme ressalta Demo (1998, p. 07).

Ressalto ainda a importância da UFMS/CPAQ em toda minha formação, bem como o compromisso social na extensão do conhecimento a toda população Aquidauanense, proporcionada através da magnitude deste projeto. 


\subsection{CONSIDERAÇÕES FINAIS}

É importante ressaltar que a oportunidade de elaboração de um projeto de extensão nos moldes do Programa Novos Talentos, só foi possível porque a proposta do edital da Coordenação de Aperfeiçoamento de Pessoal de Nível Superior - CAPES/Brasil, condicionou essa interligação necessária da Universidade com a Educação Básica. Essa visão de educação passa a ser um diferencial na elaboração e abertura de editais, promovendo a aproximação e efetivação de resultados em diferentes níveis. Ratifica-se, portanto, a magnitude dos resultados efetivos na sociedade quando se valoriza a contemplação de todas as áreas do conhecimento, indistintamente, no fomento à produção científica, que consiste no principal meio de impulso ao desenvolvimento e progresso de um País, amplamente discutido na geografia.

A participação no projeto exigiu de nós professores do ensino superior e professores da educação básica de áreas diferentes, juntamente com acadêmicos dos cursos da Universidade e alunos do ensino fundamental, o trabalho em equipe, como integrantes de uma só ação, na busca pela unidade no aprendizado e valorização da descoberta científica a partir da curiosidade e das necessidades vivenciadas pela sociedade, culminando na interpretação, análise, discussão, troca e consequente produção/resultado. Enfim, é preciso destacar que consideramos a interdisciplinaridade uma busca incessante, uma dinâmica que exige lidar com o contraditório, assim como a construção do saber científico. Nesse sentido, as etapas do processo de ensinoaprendizagem do projeto permitiram uma riqueza inigualável para aproximação do que julgamos qualidade na educação.

\section{REFERÊNCIAS BIBLIOGRÁFICAS}

AYACH, L. R.; BATISTA, R. L; FARIAS, F. R. Os desafios da formação de professores de geografia na UFMS, Câmpus de Aquidauana: a aula de campo como perspectiva interdisciplinar. Bauru: Revista Ciência Geográfica, vol. XXIV, n. 1, p. 111-126, Janeiro/Dezembro de 2020.

BRASIL. Secretaria de Educação Fundamental. Parâmetros curriculares nacionais: geografia / Secretaria de Educação Fundamental. Brasília: MEC/ SEF, 1998. http://basenacionalcomum.mec.gov.br/images/pcn/geografia.pdf

DEMO, Pedro. Educar pela pesquisa. 3 . Ed.. Campinas, SP: Autores Associados, 1998.

GUIMARÃES, S. T. L. Percepção ambiental e conservação de recursos paisagísticos em áreas de turismo rural e ambiental. In: FERREIRA, Y.N. (Org.). Construção do saber urbano 
ambiental: a caminho da transdisciplinaridade. Londrina: Humanidades, 2002. p. 334345.

GOMES, Paulo Cesar da Costa, e Vincent Berdoulay. "Imagens na geografia: importância da dimensão visual no pensamento geográfico." Cuadernos de Geografía: Revista Colombiana de Geografía, v. 27, n. 2, p. 356-371, 2018.

GONZALES-BERNADEZ, F. Ecologia y paisaje. Ed. H. Blume, 250p., 1981.

PERH-MS. PLANO ESTADUAL DE RECURSOS HÍDRICOS. Consolidação da etapa de diagnóstico do plano estadual de recursos hídricos de Mato Grosso do Sul. Campo Grande: Secretaria de Recursos Hídricos e Ambiente Urbano, 2008. 208 p.

THIESEN, Juares da Silva. A interdisciplinaridade como um movimento articulador no processo ensino-aprendizagem. Revista Brasileira de Educação, v. 13 n. 39 set./dez. 2008.

TUAN, Y-F. Espaço e Lugar: a perspectiva da experiência. São Paulo: Difel, 1983. 


\section{CAPITULO III}

\section{QUALIDADE DA ÁGUA DO RIO AQUIDAUANA}

Dirce Ferreira Luz ${ }^{1}$

Tamara Ferreira da Silva ${ }^{2}$

Sirlei Fernandes Marciel ${ }^{2}$

1. Docente do Curso de Ciências Biológicas da Universidade Federal de Mato Grosso do Sul, Campus de Aquidauana, Rua Oscar Trindade de Barros, 740, Bairro da Serraria, Aquidauana, MS, Brasil, 79200-000.

2. Graduada em Ciências Biológicas, Universidade Federal de Mato Grosso do Sul, Campus de Aquidauana, Rua Oscar Trindade de Barros, 740, Bairro da Serraria, Aquidauana, MS, Brasil, 79200-000.

A qualidade da água do Rio Aquidauana foi avaliada por meio de ações desenvolvidas no "Projeto Aquidauana: um rio de saberes desaguando no Pantanal”, através de uma iniciativa dos cursos de Ciências Biológicas, Geografia, Letras e Pedagogia da Universidade Federal de Mato Grosso do Sul (UFMS) em parceria com o Instituto Federal de Mato Grosso do Sul (IFMS) e das escolas estaduais Antônio Salústio Areias e Marechal Deodoro da Fonseca, e financiado pela CAPES, Coordenação de Aperfeiçoamento de Pessoal de Nível Superior.

Além das avaliações da qualidade da água propriamente dita, em especial dos teores físicos, químicos e microbiológicos, o Projeto visou também conscientizar e sensibilizar a população aquidauanense, sobre a importância do Rio Aquidauana para o bem-estar dos munícipes.

0 rio Aquidauana, além dos aspectos ambientais, é vital para as pessoas que vivem na cidade, pois a água do rio ainda representa a principal fonte de água doce utilizada pela população, sendo a água coletada diretamente do manancial, purificada e armazenada em reservatórios próprios na Estação de Tratamento de Água (ETA). Existe assim, um controle rigoroso da sua qualidade por meio da avaliação periódica dos seus parâmetros físicos, químicos e microbiológicos, sendo que somente após o seu tratamento a água é escoada por meio de tubulações e partilhada para a população através do cavalete, que é a rede de distribuição, constituinte do sistema público de abastecimento de água.

Neste Projeto as amostras de água foram coletadas a jusante da Estação de Tratamento de Água (ETA), de forma a obter amostras de água similares à utilizada pela população de 
Aquidauana. A descida do rio foi efetuada com um barco, numa manhã ensolarada e sem condições climáticas adversas nos dias que precederam a viagem. As amostras de água foram acondicionadas em frascos estéreis, etiquetadas e mantidas em temperatura ambiente, para posterior determinação no Pesqueiro Itaju, por meio de indicadores químicos, dos parâmetros físico-químicos, como o potencial hidrogeniônico $(\mathrm{pH})$, a acidez, a alcalinidade e a dureza.

O potencial hidrogeniônico é um importante parâmetro químico para o controle de qualidade da água, pois representa a intensidade das condições ácidas ou alcalinas do meio líquido por meio da medição da presença de íons hidrogênio $\left(\mathrm{H}^{+}\right)$(BRASIL, 2006). De acordo com a portaria n 2.914, de 12 de dezembro de 2011, do Ministério da Saúde, que define o padrão de potabilidade das águas, o $\mathrm{pH}$ da água própria para consumo humano deve ser mantido na faixa de 6,0 a 9,5 (BRASIL, 2011). Já para a água em condições naturais, a legislação federal por meio da Resolução ${ }^{\circ} 357$ do CONAMA, de março de 2005, indica faixas de pH pré-estabelecidas para as diversas classes de águas.

A influência do $\mathrm{pH}$ sobre os ecossistemas aquáticos naturais dá-se diretamente devido a seus efeitos sobre a fisiologia das diversas espécies. Também o efeito indireto é muito importante, podendo determinadas condições de $\mathrm{pH}$ contribuir para a precipitação de elementos químicos tóxicos como metais pesados; outras condições podem exercer efeitos sobre a solubilidade de nutrientes. Segundo CETESB, (1987) no cálculo do Índice de Qualidade das Águas (IQA), valores abaixo de 7 e próximos de zero indicam aditamento de acidade, enquanto valores de 7 a 14 indicam aumento da alcalinidade. Desta forma, os critérios de proteção à vida aquática fixam o pH entre 6 e 9.

A acidez de uma água pode ser definida como sua capacidade de reagir quantitativamente com uma base forte até um valor definido de pH, devido à presença de ácidos fortes, como os minerais (clorídrico, sulfúrico, nítrico, etc.); ácidos fracos, como os orgânicos (acético) e inorgânicos (ácido carbônico); e os sais que apresentam um caráter ácido, como o sulfato de alumínio, cloreto férrico e cloreto de amônio.

A grande importância no controle da acidez das águas reside nos estudos de corrosão, que pode ser provocada tanto pelo gás carbônico, presente em águas naturais, como pelos ácidos minerais presentes em efluentes industriais. Todavia, CONAMA (2005) ressalta que não há praticamente nenhuma relação da qualidade da água com o gás carbônico, sob o ponto de vista da saúde pública. Os ácidos minerais que possivelmente teriam, são identificados pela manifestação de sabor azedo em concentrações relativamente baixas. Desta forma, o parâmetro acidez não se constitui, apesar de sua importância, em qualquer tipo de padrão, seja de 
potabilidade, de classificação das águas naturais ou de emissão de esgotos; sendo o efeito da acidez controlado legalmente pelo valor do $\mathrm{pH}$.

Alcalinidade de uma amostra de água pode ser definida como sua capacidade de reagir quantitativamente com um ácido forte até um valor definido de $\mathrm{pH}$. A alcalinidade das águas não representa risco potencial à saúde pública. No entanto, provoca alteração no paladar e a rejeição da água em concentrações inferiores àquelas que eventualmente pudessem trazer prejuízos mais sérios. A alcalinidade não se constitui em padrão de potabilidade, ficando este efeito limitado pelo valor do $\mathrm{pH}$ (KATO, 1983).

Dureza da água é a medida da sua capacidade de precipitar sabão, isto é, nas águas que a possuem os sabões transformam-se em complexos insolúveis, não formando espuma até que o processo se esgote. É causada pela presença de cálcio e magnésio, principalmente, além de outros cátions como ferro, manganês, estrôncio, zinco, alumínio, hidrogênio, etc.; associados a ânions carbonato, mais propriamente ao bicarbonato, que é mais solúvel, e sulfato, principalmente, além de outros ânions como nitrato, silicato e cloreto. São quatro os principais compostos que conferem dureza às águas: bicarbonato de cálcio, bicarbonato de magnésio, sulfato de cálcio e sulfato de magnésio. Nas águas naturais, a dureza é uma condição importante, por formar complexos com outros compostos, modificando seus efeitos sobre os constituintes daquele ecossistema. Por isso, a dureza é um parâmetro tradicionalmente utilizado na avaliação de toxicidade de substâncias ou de efluentes (SILVEIRA, 2004).

Além das avaliações físico-químicas, parte das amostras de água foi levada para o Laboratório de Microbiologia (MICROLAB) do Curso de Ciências Biológicas da UFMS/CPAQ (Figura 1), para a execução das análises microbiológicas, como o Número Mais Provável de Coliformes (NMP) a 35 e a $45^{\circ} \mathrm{C}$, de forma a se obter o número de Coliformes Totais (CT) e Escherichia coli. A principal bactéria dos coliformes fecais é a Escherichia coli. Ela promove febre, dor de barriga, diarreia, vômitos, calafrios. Crianças e idosos são mais vulneráveis quando contaminados com essa bactéria, porque ela é mais agressiva nessa faixa etária.

Para se avaliar o Número Mais Provável (NMP) de coliformes a 45ํㅡ, primeiramente se fez necessário uma análise dos coliformes a $35^{\circ} \pm 1^{\circ} \mathrm{O}$. 0 procedimento empregado estava de acordo com APHA, 2000. Assim, foi utilizada a técnica dos tubos múltiplos, com 3 tubos por diluição, para determinação do NMP de Coliformes Totais (CT) por mL de água. 0 meio utilizado foi o Caldo Lactosado Verde Brilhante e Bile (VBB) à $2 \%$, com incubação dos tubos a $35^{\circ} \mathrm{C}$ durante 24 a 48 horas. Em seguida, os tubos contendo o VBB positivos foram replicados para tubos com caldo Escherichia coli suplementado com 4 metil umbeliferil $\beta$-D glucoronídeo (EC-MUG), 
utilizado para determinar de forma simultânea, a presença de CT e Escherichia coli. Após a incubação a $44,5-45,0^{\circ} \mathrm{C}$ durante 24 horas, o número dos tubos com crescimento positivo para a presença de coliformes a 45,0C foram identificados pela turbidez e pela presença de gás no tubo e assim, a determinação do NMP/mL foi aferida. Além disso, os tubos positivos foram semeados em Agar Levine Eosina Azul de Metileno (EMB Levine), em busca de colônias características de Escherichia coli.

Figura 1. Coleta da água no rio Aquidauana, análises físico-químicas e dos parâmetros microbiológicos em laboratório de Microbiologia da UFMS/CPAQ.
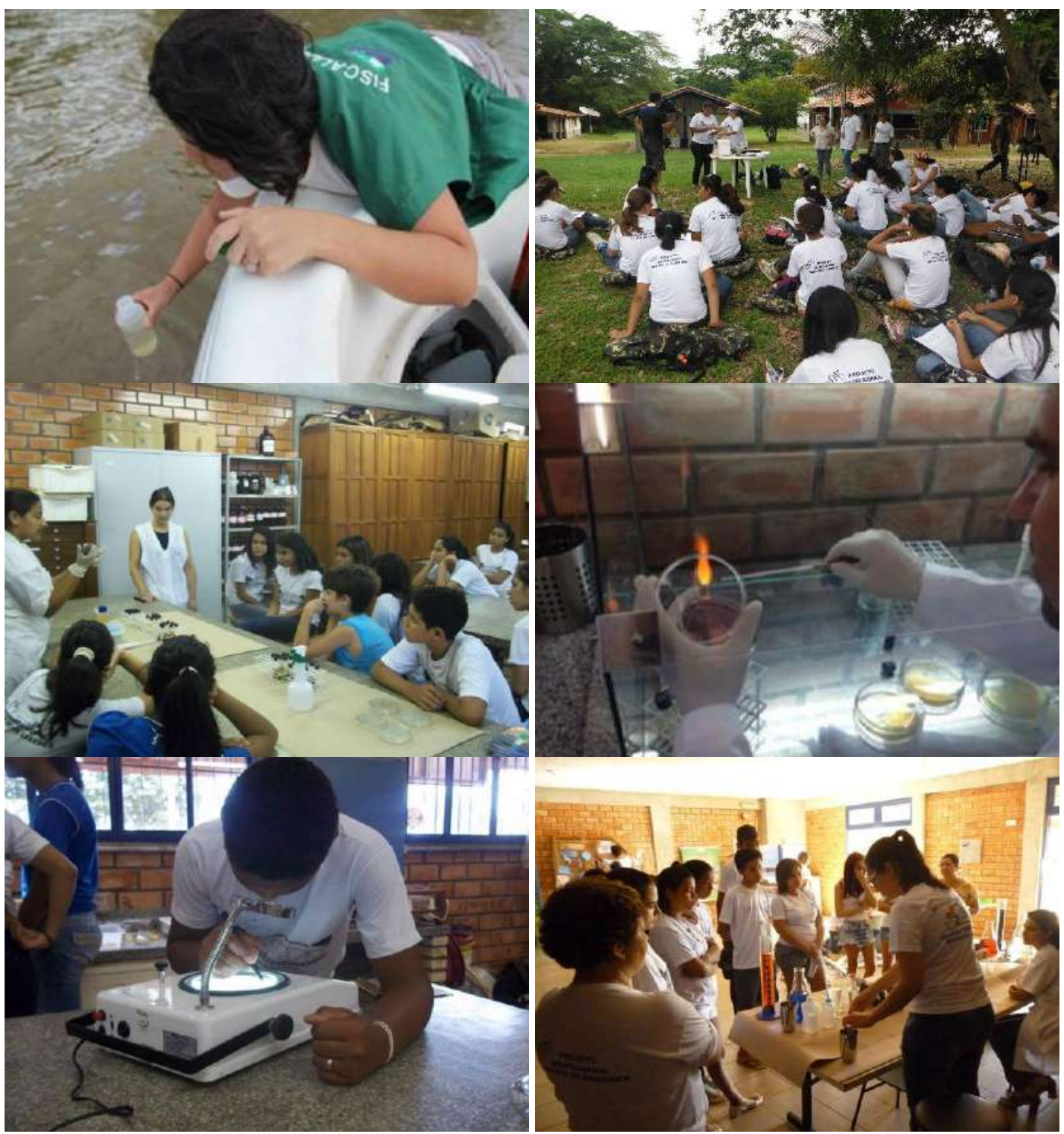

A água de consumo humano é um dos importantes veículos de enfermidades diarréicas de natureza infecciosa, o que torna primordial a avaliação de sua qualidade microbiológica (ISAAC-MARQUEZ et al., 1994). As doenças de veiculação hídrica são causadas principalmente 
por microrganismos patogênicos de origem entérica, animal ou humana, transmitidos basicamente pela rota fecal-oral, ou seja, são excretados nas fezes de indivíduos infectados e ingeridos na forma de água ou alimento contaminado por água poluída com fezes (GRABOW, 1996).

Todas as amostras de água estavam dentro dos padrões físico-químicos e microbiológicos estabelecidos pelos órgãos de fiscalização vigentes no município de Aquidauana, MS.

Ressalta-se que posteriormente o tema "Qualidade da água" foi trabalhado em sala de aula pelos acadêmicos da Universidade Federal de Mato Grosso do Sul, Campus de Aquidauana (UFMS/CPAq), numa metodologia de aprender-fazendo, com estímulos a interdisciplinaridade, bem como nas questões socioambientais, manutenção da qualidade e diversidade ambiental. $O$ assunto também foi debatido de maneira construtiva pelos alunos e professores do Instituto Federal de Mato Grosso do Sul (IFMS) e das escolas estaduais Antônio Salústio Areias e Marechal Deodoro da Fonseca.

Pode-se, portanto, ampliar de maneira significativa a dispersão das informações à toda a comunidade estudantil e ainda incentivar os acadêmicos da UFMS, IFMS e alunos da rede pública, de modo a promover uma maior motivação, anseio e desejo para a continuidade de seus estudos na área ambiental. Desta forma, a caracterização da qualidade da água do Rio Aquidauana, em termos químico, físico e microbiológico teve seus objetivos plenamente concretizados.

\subsection{CONSIDERAÇÕES FINAIS}

A união de esforços de toda a equipe de trabalho, em especial dos acadêmicos e professores, num ambiente de mútua colaboração, onde os participantes foram os principais protagonistas na coleta e disponibilização das informações técnicas acerca das características da água do rio Aquidauana, foi de encontro ao anseio das pessoas que buscam uma cidade sustentável e mais integrada com a natureza.

Condições estas de suma importância para manter a preservação do Pantanal e, consequentemente o seu equilíbrio ecológico e ambiental, haja vista a grande biodiversidade de plantas e animais que dependem do rio Aquidauana para sobreviverem, como dezenas de espécies de peixes, jacarés, ariranhas, capivaras, veados, serpentes, macacos, onças e centenas de pássaros, como o jaburu, periquitos, tucanos e araras. 


\section{REFERÊNCIAS BIBLIOGRÁFICAS}

APHA - American Public Health Association. Standard Methods for the Examination of Water and Wastewater. 20th. Ed. Washington, D.C., 2000, 573p.

BRASIL. Ministério da Saúde. Portaria no 2.914, de 12 de dezembro de 2011. Dispõe sobre os procedimentos de controle e de vigilância da qualidade da água para consumo humano e seu padrão de potabilidade. Diário Oficial da União, Poder Executivo, Brasília, DF, 14 dez. 2011, Seção $1 . \quad$ Disponível em: http://site.sabesp.com.br/site/uploads/file/asabesp_doctos/PortariaMS2914121 22011.pdf>. Acesso em 28 de fev. 2020.

BRASIL. Ministério da Saúde. Agência Nacional de Vigilância Sanitária. Resolução RDC n 173 de 13 de setembro de 2006. Regulamento técnico de boas práticas para industrialização e comercialização de água mineral natural e de água natural e a lista de verificação das boas práticas para industrialização e comercialização de água mineral natural e de água natural. Diário Oficial da República Federativa do Brasil, Brasília, 2006. Disponível em: < http://bvsms.saude.gov.br/bvs/saudelegis/anvisa/2006/rdc0173_13_09_2006.ht ml>. Acesso em 28 de fev. 2020.

CETESB - Companhia de Tecnologia de Saneamento Básico. Guia de Coleta e Preservação de Amostras de Água. São Paulo, 1987. 150p.

CONAMA - Conselho Nacional de Meio Ambiente. Ministério do Meio Ambiente. Resolução $\mathrm{n}^{\circ}$ 357/2005, Brasília/DF, 2005. Disponível em: < http://www2.mma.gov.br/port/conama/ >. Acesso em 28 de fev. 2020.

GRABOW W. Waterborne diseases: update on water quality assessment and control. Water $S . A$;v. 22, p. 193-202, 1996.

ISSAC-MARQUEZ AP, LEZAMA-DAVILA CM, KU-PECH RP, TAMAY-SEGOVIA P. Calidad sanitaria de los suministros de agua para consumo humano en Campeche. Salud Pública Méx v. 36, p. 655-61, 1994.

KATO, M.T. “Dureza”. Curso Qualidade da Água, do Ar e do Solo. Escola de Engenharia Mauá. São Caetano do Sul/SP, 1983.

SILVEIRA, M.P. Aplicação do Biomonitoramento para Avaliação da Qualidade da Água em Rios. Embrapa Meio Ambiente. Jaguariúna, 2004, 68p. 


\title{
CAPITULO IV
}

\section{EDUCAÇ̃̃ AMBIENTAL PARA A CONSERVAÇ̃̃O DA FAUNA SILVESTRE NO PANTANAL}

\author{
Camila Aoki 1, 2, 3 \\ Bruno Arguelho Arrua 4 \\ Crisley Helena Simão ${ }^{5}$ \\ Gabriela Canella Gregório ${ }^{6}$ \\ Joana Roxinsky Teodoro ${ }^{4}$ \\ Maria Helena da Silva ${ }^{4}$
}

\begin{abstract}
1. Docente do Curso de Ciências Biológicas da Universidade Federal de Mato Grosso do Sul, Campus de Aquidauana, Rua Oscar Trindade de Barros, 740, Bairro da Serraria, Aquidauana, MS, Brasil, 79200-000.

2. Docente do Programa de Pós-Graduação em Recursos Naturais, Faculdade de Engenharias, Arquitetura e Urbanismo e Geografia (FAENG), Av. Costa e Silva, s/n - Cidade Universitária, Campo Grande, MS, Brasil, 79070-900.

3. Docente do Programa de Pós-Graduação em Biologia Vegetal, Instituto de Biociências (INBIO), Av. Costa e Silva, s/n - Bairro Universitário, Campo Grande, MS, Brasil, 79070-900.

4. Mestre pelo Programa de Pós-Graduação em Ecologia e Conservação, Instituto de Biociências (INBIO), Av. Costa e Silva, s/n Bairro Universitário, Campo Grande, MS, Brasil, 79070-900.

5. Mestre pelo Programa de Pós-Graduação em Ensino de Ciências, Instituto de Física (INFI), Av. Costa e Silva, s/n - Bairro Universitário, Campo Grande, MS, Brasil, 79070-900.

6. Graduada em Ciências Biológicas, Universidade Federal de Mato Grosso do Sul, Campus de Aquidauana, Rua Oscar Trindade de Barros, 740, Bairro da Serraria, Aquidauana, MS, Brasil, 79200-000.
\end{abstract}

O Brasil detém a maior variabilidade genética do mundo, no território nacional ocorrem importantes recursos de valor estratégico que são a fonte também de serviços ambientais essenciais para a manutenção da sociedade planetária (PRATES; IRVING, 2015). Segundo as estimativas mais conservadoras, o Brasil abriga $13,2 \%$ da biota mundial, o que significa cerca de 207.000 espécies conhecidas e 1,8 milhões de espécies estimadas incluindo aquelas ainda desconhecidas pela ciência (LEWINSOHN, 2006).

Em relação às riquezas naturais, o Brasil possui seis biomas continentais e o maior sistema fluvial do mundo, destacando-se no plano global, por abrigar a mais rica biota continental do planeta (BRANDON et al., 2005). 0 território brasileiro abriga entre 15\% e 20\% de toda a biodiversidade mundial além do maior número de espécies endêmicas, a maior floresta 
tropical (a Amazônia), dois hotspots mundiais (a Mata Atlântica e o Cerrado) (DRUMMOND; ANTONINI, 2006) e o Pantanal, uma das maiores extensões úmidas contínuas do globo (GIRARD; VARGAS, 2008).

Os impactos humanos no meio ambiente são crescentes e estão prejudicando as espécies e os ecossistemas da Terra a taxas cada vez maiores (STEFFEN et al., 2015). Caça excessiva, mudança no uso da terra e fragmentação de habitat, espécies invasoras e poluição já ameaçam $25 \%$ de todas as espécies de mamíferos, $14 \%$ de todas as espécies de aves e 41\% dos anfíbios além de mais de 31.000 outras espécies de plantas e outros animais estão ameaçados de extinção (IUCN, 2020). 0 Pantanal tem sido impactado por práticas não sustentáveis de desenvolvimento socioeconômico, dentre as quais, podemos destacar a pecuária, pesca, agricultura, mineração e turismo (ALHO, 2008).

Os sistemas da Terra estão experimentando intensa pressão nos ciclos biológicos, químicos e geológicos, resultantes do uso excessivo de recursos induzidos pelo homem, em uma magnitude nunca antes experimentada (BARNOSKY; HADLY, 2016). Diante das diversas ameaças que vêm comprometendo a biodiversidade, ações de educação ambiental que sejam voltadas para a conservação são de extrema importância. Por definição, a educação ambiental abrange abordagens, ferramentas e programas que desenvolvem e apoiam atitudes, valores, conscientização, conhecimento e habilidades relacionadas ao meio ambiente que preparam as pessoas para agirem em favor deste (UNESCO, 1978; MONROE; KRASNY, 2016).

Apesar das dificuldades enfrentadas para a elaboração de um plano de conservação e manejo para a biodiversidade do Pantanal, Alho et al. (2019) apontam duas razões para otimismo: (1) a crescente conscientização do povo brasileiro em geral, e do pantaneiro em particular, com relação à necessidade da proteção da biodiversidade na região e (2) a crescente certeza de que a conservação da biodiversidade, além de seu valor intrínseco, pode também promover benefícios socioeconômicos, pela aptidão que a região tem para promover o uso sustentável do turismo, da pesca e de outros usos racionais da riqueza biológica do Pantanal.

\subsection{ATIVIDADES DESENVOLVIDAS NO PROJETO}

Este relato de experiência refere-se a atividades desenvolvidas semanalmente na Universidade Federal de Mato Grosso do Sul, no período de outubro de 2013 a julho de 2015, onde foram realizadas palestras, oficinas, aulas práticas em laboratório e na sala de informática. Também foram realizadas atividades de campo e viagens técnicas, visando oportunizar um 
processo de ensino-aprendizagem diferenciado, incluindo a reflexão dos diversos temas que o projeto envolveu. Este projeto contemplou 25 alunas/os, que no início do projeto estavam matriculados no $6^{0}$ ano em duas escolas estaduais localizadas no município de Aquidauana Antônio Salústio Areias e Marechal Deodoro da Fonseca.

As atividades relacionadas à fauna silvestre contemplaram especialmente a reflexão dos seguintes conteúdos: caracterização de animais silvestres, identificação de sons, hábitos e vestígios da fauna local e discussões sobre os impactos antrópicos na conservação desta biodiversidade. Essas atividades tiveram como objetivo despertar e/ou aumentar a curiosidade de adolescentes de escolas públicas de Aquidauana (MS) em observar e ter um olhar crítico e investigativo sobre a fauna e suas relações com o ambiente. Para atingir esse objetivo, foram construídos materiais didáticos e recursos multimídias contendo estratégias teóricas e práticas que estimulassem o raciocínio e o diálogo sobre o (re)conhecimento e conservação da fauna silvestre regional. Duas dessas atividades seguem descritas abaixo, em forma de subtópicos. Como forma de avaliar a eficácia das atividades, disponibilizamos questionários, os quais poderiam ser respondidos de forma espontânea, sem necessidade de identificação. De forma a ter um grupo controle, os questionários eram disponibilizados para os participantes do projeto e também para os colegas que não faziam parte do mesmo.

\subsubsection{TRILHAS INTERPRETATIVAS}

Os alunos percorreram trilhas pré-existentes na Base de Estudos do Pantanal (BEP) da Universidade Federal de Mato Grosso do Sul, em Corumbá (MS) e no Parque Estadual do Prosa em Campo Grande (MS) (Figura 1). Em ambas as trilhas os alunos foram guiados por professores e monitores, foram avistadas espécies nativas do Pantanal e Cerrado e foram discutidas informações a respeito de ecologia, comportamento, hábito e habitat, bem como status de conservação. Essas discussões aconteceram em campo e também em sala de aula, as quais incluíram rápidas palestras. Para testar a efetividade da atividade, solicitamos os alunos listassem os animais pertencentes à fauna regional que eles conheciam. Ao todo, 22 alunos que participaram das trilhas e 16 alunos que não participaram da atividade responderam ao questionário de forma anônima e espontânea. 
Figura 1. Etapas do desenvolvimento da atividade relacionada às trilhas interpretativas. Fonte: Camila Aoki e Bruno Arguelho Arrua.
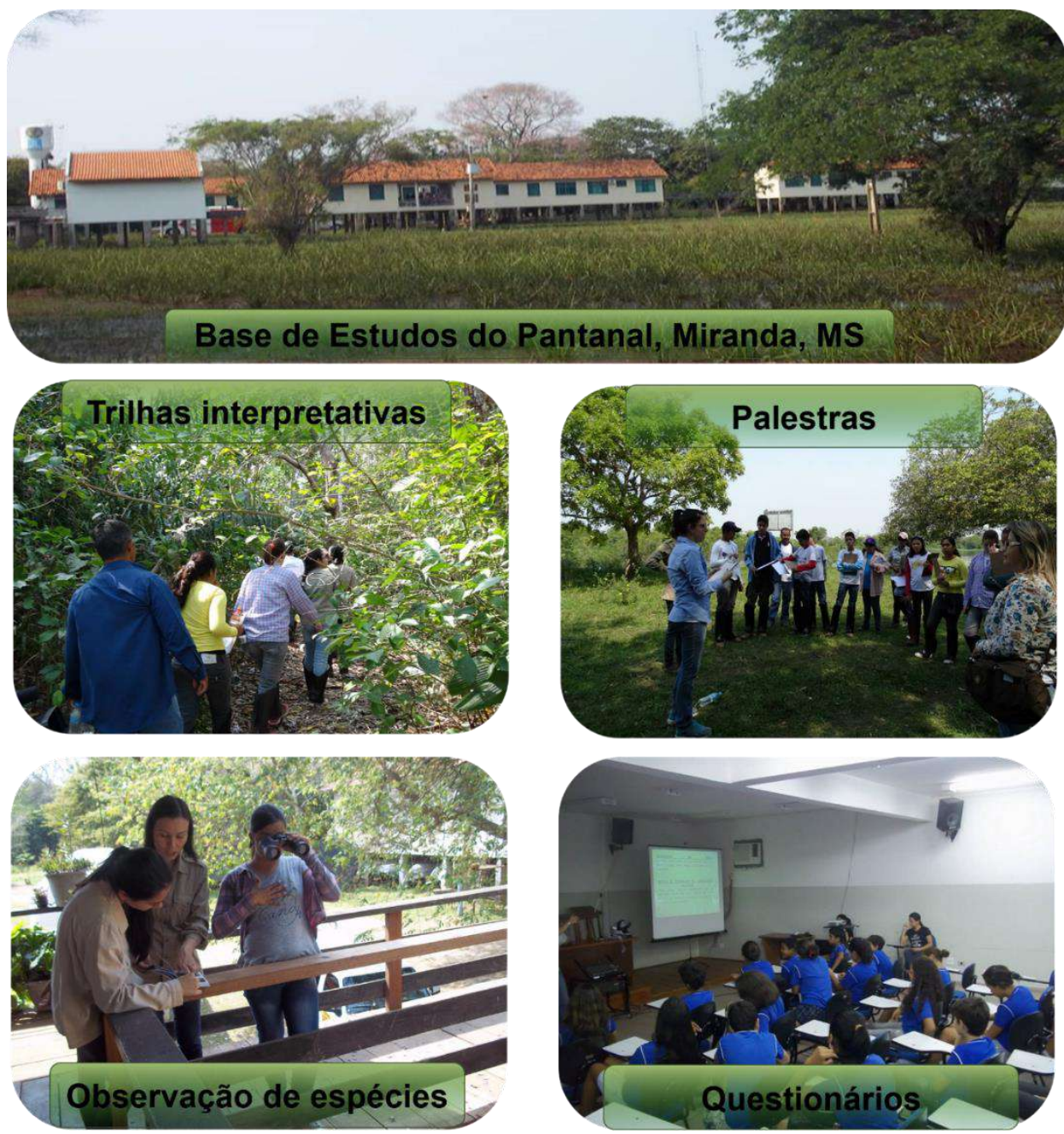

Os alunos que participaram das trilhas interpretativas citaram 70 animais no questionário, sendo três deles exóticos. Cada aluno citou em média 13,3 $( \pm 6,3)$ animais. Os mamíferos foram os animais mais citados (37\% das espécies), dentre eles destacaram-se a capivara, citada em $81,8 \%$ dos questionários, a anta, o bugio e a onça citados em $50 \%$ dos questionários. Aves constituíram o segundo grupo mais citado (31,4\% das espécies), sendo que o tuiuiú foi citado por $40,9 \%$ dos alunos e o gavião e o martim-pescador por 27,3\%. Dentre os alunos que não participaram das atividades, foram citadas 45 espécies, sendo duas delas exóticas. Cada aluno deste grupo citou em média $7,2( \pm 3,4)$ animais, um número significativamente menor que o citado pelos participantes do projeto. Mamíferos constituíram $48,9 \%$ das espécies e aves $24,4 \%$. Capivara e onça foram os mamíferos mais citados $(62,5 \%$ dos questionários) e o tuiuiú entre as aves (50\%). Répteis, peixes e anfíbios também foram lembrados por ambos os grupos, com destaque para o jacaré que foi citado por $81,8 \%$ dos alunos 
que participaram das atividades e por $75 \%$ dos alunos que não participaram. Importante ressaltar que apenas o grupo que participou das atividades citou invertebrados na resposta (seis espécies), sendo que as borboletas foram citadas por $63 \%$ dos alunos e as libélulas por 50\%.

O número de espécies citadas pelos alunos que participaram das trilhas pode ser considerado alto se comparado a estudos realizados em outras localidades brasileiras. A realização de atividades práticas promoveu uma maior percepção dos alunos quanto à fauna que o rodeia. Um dos estudos com a maior citação de animais foi o de Berlinck e Lima (2007) trabalhando com uma comunidade rural de Goiás, no qual foram citadas 52 espécies. Semelhante ao registrado em outros trabalhos, os mamíferos e aves constituem os grupos mais citados (RAZERA et al., 2006; BERLINCK; LIMA, 2007). As espécies mais citadas constituem espécies comuns na região. Dentre os peixes, as espécies mais citadas neste estudo são utilizadas corriqueiramente na alimentação humana (dourado e pintado), sendo a pesca uma prática comum na região, inclusive no rio que corta a cidade (rio Aquidauana). Invertebrados que, a despeito de sua grande importância ecológica e econômica, geralmente são pouco valorizados pela população e pouco citados em questionários nos demais estudos (RAZERA et al., 2006; BERLINCK; LIMA, 2007), tiveram uma elevada frequência nas respostas dos alunos que participaram das atividades práticas. Isso se deve ao fato destes animais terem sido inseridos nas observações e explicações durante as trilhas.

\subsubsection{USO DE MOLDES DE PEGADAS COMO INSTRUMENTO DE EDUCAÇÃO E PRESERVAÇÃO AMBIENTAL}

Os moldes das pegadas foram usados para demonstrar a variedade de mamíferos que ainda vivem na região (Figura 2). Além dos moldes, também foram apresentadas imagens (vídeos e fotos em datashow) sobre os hábitos e habitats destes mamíferos. Para reforçar a aprendizagem foram discutidos os fatores responsáveis pela diminuição do número de espécies ao longo do tempo e a necessidade de conservação dos remanescentes vegetais da região para possibilitar a continuidade dos animais ainda encontrados. Para auxiliar nas análises sobre os conhecimentos prévios dos alunos e na verificação do aprendizado após as oficinas, foi aplicado um questionário contendo cinco questões dissertativas. 0 mesmo questionário foi aplicado para alunos das mesmas escolas e série, mas que não participaram das atividades. 
Figura 2. Etapas do desenvolvimento da atividade relacionada aos moldes de pegada. Fonte: Camila Aoki
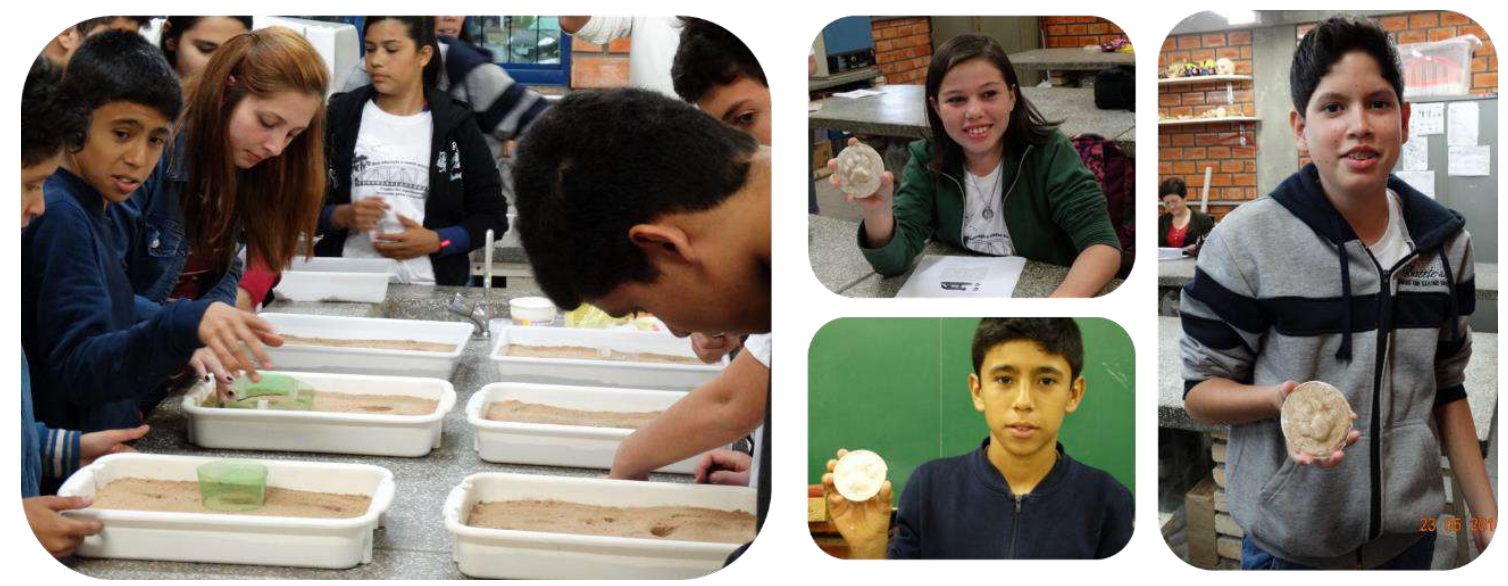

No decorrer do projeto foram confeccionados moldes de pegadas de oito espécies da fauna silvestre do Pantanal. Esses moldes, além de servirem como instrumento para melhorar a percepção ambiental dos alunos, foram utilizados pelos mesmos em feira de ciências de ambas as escolas, propagando assim a informação. Entre os alunos que participaram da atividade, todas as questões tiveram o mínimo de 70,6\% e máximo de 94\% acerto. Entre os alunos que não participaram das atividades, a taxa de acerto variou de $18,2 \%$ a $81,8 \%$. Nenhuma das questões foi respondida corretamente por todos os alunos. Entre as perguntas realizadas, a "Você considera importante conservar as espécies de mamíferos? Por quê?", teve resposta sim de todos os alunos, e na justificativa $47 \%$ dos alunos que participaram da atividade incluíram o risco de extinção, 23,5\% a participação na cadeia alimentar e 17,7\% citaram a interdependência entre os seres, além de outras respostas. Entre os alunos que não participaram da atividade, 18,2\% citaram a extinção e a cadeia alimentar e 9\% citaram a interdependência, sendo essas as respostas com maior frequência em ambos os grupos.

A identificação de rastros e de pegadas possui caráter educativo, ela pode ser utilizada para auxiliar discussões que envolvam conceitos relacionados à valorização da biodiversidade local, inclusive complementando o conteúdo curricular. Sua utilização foi citada como atividade prática a ser realizada no Bioma Pantanal (SAITO, 2006 apud BERLINCK; LIMA, 2007), todavia sua utilização pode ser expandida para todos os Biomas. Os processos educativos que envolvem a discussão da conservação ambiental, em especial da biodiversidade, necessitam ultrapassar a pura sensibilização e contribuir para o desenvolvimento da responsabilidade ambiental (BERLINCK; LIMA, 2007). 


\subsection{CONSIDERAÇÕES FINAIS}

Experiências de infância na natureza, incluindo experiências diretas como pesca, acampamento, captura de insetos, coleta de plantas e trilhas (LEKIES; BRENSINGER, 2015; SOGA et al., 2016) e experiências indiretas como aquelas através de TV, livros e sites (EAGLES; MUFFITT, 1990; SOGA et al., 2016), são conhecidos por promover preferências, competências e preocupações ambientais (BIXLER; FLOYD, 1997; CHAWLA, 1999; BIXLER et al., 2002; WELLS; LEKIES, 2006). Todavia, as experiências diretas costumam ter maiores impactos que as indiretas (CHAWLA, 1999). Levando isso em consideração, tentamos neste projeto, promover várias atividades que incluíssem experiências diretas, mas também indiretas, como forma de aprendizagem e promoção de valorização da biodiversidade, no intuito de formar cidadãos ambientalmente conscientes e capazes de reflexões mais aprofundadas sobre o tema.

Há estudos demonstrando que alunos do ensino fundamental e médio que relataram ter desenvolvido atividades em ambientes naturais ou selvagens mostraram percepções mais positivas em relação a esses ambientes (BIXLER et al., 2002; BJERKE; ØSTDAHL, 2004; SOGA et al., 2016; ZHANG et al., 2014). Esses resultados sugerem que as experiências infantis na natureza têm um papel fundamental na formação de atitudes afetivas em relação a vários tipos de animais (ARDOIN et al., 2020). Portanto, é importante traçar estratégias em programas de conservação para oferecer às crianças oportunidades de interagir com a natureza (como a coleta de plantas e observação de animais). Esses estudos corroboram a hipótese de que a biofilia (amor à vida ou sistemas vivos), independentemente de ser inata ou não, é fortemente desencadeada pelo contato com a natureza na infância (ARDOIN et al., 2020).

\section{REFERÊNCIAS BIBLIOGRÁFICAS}

ALHO, C.J.R.; MAMEDE, S.B.; BENITES, M.; ANDRADE, B.S.; SEPÚLVEDA, J.J.O. Ameaças à biodiversidade do Pantanal brasileiro pelo uso e ocupação da terra. Ambiente \& Sociedade, v. 22, 2019.

ALHO C.J.R. Biodiversity of the Pantanal: response to seasonal flooding regime and to environmental degradation. Brazilian Journal of Biology, v. 68, n. 4, 2008.

ARDOIN, N.M.; BOWERS, A.W.; GAILLARD, E. Environmental education outcomes for conservation: A systematic review. Biological Conservation, v. 241, 108224, 2020.

BARNOSKY, A.D.; HADLY, E.A. Tipping point for planet earth: how close are we to the edge? Thomas Dunne Books, New York, 2016. 
BERLINCK, C.N.; LIMA, L.H.A. Identificação de rastros de animais, educação ambiental e valorização da fauna local no entorno do Parque Estadual de Terra Ronca (GO). Rev. eletrônica Mestr. Educ. Ambient, v. 18, p. 174-189, 2007.

BIXLER, R.D.; FLOYD, M.F. Nature is scary, disgusting, and uncomfortable. Environment and Behavior, v. 29, n. 4, p. 443-467, 1997.

BIXLER, R.D.; FLOYD, M.F.; HAMMITT, W.E. Environmental socialization - Quantitative tests of the childhood play hypothesis. Environment and Behavior, v. 34, n. 6, p. 795-818, 2002.

BJERKE, T.; ØSTDAHL, T. Animal-related attitudes and activities in an urban population. Anthrozoos, v. 17, n. 2, p. 109-129. 2004.

BRANDON, K.; FONSECA, G.A.B; RYLANDS, A.B.; SILVA, J.M.C. Conservação Brasileira: desafios e oportunidades. Megadiversidade, Rio de Janeiro, v. 1, n. 1, p. 7-13, 2005.

CHAWLA, L. Life paths into effective environmental action. The Journal of Environmental Education, v. 31, n. 1, p. 15-26, 1999.

DRUMMOND, G.M.; ANTONINI, Y.A. contribuição da Fundação Biodiversitas para a implementação do art. 7ํ da Convenção sobre Diversidade Biológica. In: BENSUSAN, Nurit (Ed.) et al. Biodiversidade: para comer, vestir ou passar no cabelo? São Paulo: Peirópolis, 2006.

EAGLES, P.F.J.; MUFFITT, S. An analysis of children's attitudes toward animals. The Journal of Environmental Education, v. 21, n. 3, p. 41-44, 1990.

GIRARD, P.; VARGAS, I.A. Turismo, desenvolvimento e saberes no Pantanal: diálogos e parcerias possíveis. Desenvolvimento e Meio Ambiente, Editora UFPR, n. 18, p. 61-76, 2008.

IUCN. The IUCN Red List of Threatened Species. Version 2020-1. disponível em: https://www.iucnredlist.org. Acesso em 21 de maio de 2020.

LEKIES, K.S.; BRENSINGER, J.D. Childhood nature experience across residential settings: Rural, suburban, and urban. Risk, Protection, Provision and Policy, Geographies of Children and Young People, v. 12, p. 1-20. 2015.

LEWINSOHN, T. (Coord.) Avaliação do estado do conhecimento da biodiversidade Brasileira. Brasília: Ministério do Meio Ambiente - MMA, (Série Biodiversidade, 15), 2006.

MONROE, M.C.; KRASNY. M.E. Across the Spectrum: Resources for Environmental Education (3rd ed.), North American Association for Environmental Education, Washington, DC, 2016.

PRATES, A.P. L.; IRVING, M. de A. Conservação da biodiversidade e políticas públicas para as áreas protegidas no Brasil: desafios e tendências da origem da CDB às metas de Aichi. Revista Brasileira de Políticas Públicas, Brasília, v. 5, n. 1, p. 27-57, 2015. 
RAZERA, J.C.C.; BOCCARDO, L.; PEREIRA, J.P.R. Percepção sobre a Fauna em Estudantes Indígenas em uma Tribo Tupinambá no Brasil: um Caso de Etnozoologia. REEC, v. 5, n. 3, p. 466-480, 2006.

SOGA, M.; GASTON, K.; YAMAURA, Y.; KURISU, K.; HANAKI, K. Both direct and vicarious experiences of nature affect children's willingness to conserve biodiversity. International Journal of Environmental Research and Public Health, v.13, n. 6, p. 529, 2016.

STEFFEN, W.; BROADGATE, W.; DEUTSCH, L.; GAFFNEY, O.; LUDWIG, C. The trajectory of the Anthropocene: the Great Acceleration. Anthropocene Review. 2, 81-98, 2015.

UNESCO. The Tbilisi Declaration: Final Report: Intergovernmental Conference on Environmental Education. USSR, Tbilisi, 1978.

WELLS, N.M.; LEKIES, K.S. Nature and the life course: Pathways from childhood nature experiences to adult environmentalism. Children, Youth and Environments, v. 16, n. 1, p. 1-24, 2006.

ZHANG, W.Z.; GOODALE, E.; CHEN, J. How contact with nature affects children's biophilia, biophobia and conservation attitude in China. Biological Conservation, v. 177, p. 109116, 2014. 


\section{CAPITULOV}

\section{A EXTENSÃO NO (RE)CONHECIMENTO DA FLORA DO CERRADO E PANTANAL}

Bruna Gardenal Fina ${ }^{1}$ Augusto César Rodrigues ${ }^{2}$ Lidianei dos Santos Savala ${ }^{2}$ Naissa Elvis Martinez Benites ${ }^{3}$

Thaiany Alonso Rodrigues ${ }^{3}$

1. Docente do Curso de Ciências Biológicas da Universidade Federal de Mato Grosso do Sul, Campus de Aquidauana, Rua Oscar Trindade de Barros, 740, Bairro da Serraria, Aquidauana, MS, Brasil, 79200-000.

2. Mestre pelo Programa de Pós-Graduação em Biologia Vegetal, Instituto de Biociências (INBIO), Av. Costa e Silva, s/n, Bairro Universitário, Campo Grande, MS, Brasil, 79070-900.

3. Graduada em Ciências Biológicas, Universidade Federal de Mato Grosso do Sul, Campus de Aquidauana, Rua Oscar Trindade de Barros, 740, Bairro da Serraria, Aquidauana, MS, Brasil, 79200-000

0 município de Aquidauana está localizado no ecótono Cerrado/Pantanal, em área de transição entre o planalto e a planície pantaneira. É uma região com grande diversidade biológica e fácil acesso a ambientes com características dos dois ecossistemas pois há ainda muitos fragmentos de vegetação nativa (SILVA \& JOIA, 2001), constituídos principalmente por vegetação de Cerrado, em suas diferentes fisionomias.

Entretanto, por mais rica que seja a biodiversidade local, e ainda que existam fragmentos com mata nativa, o fato da economia do município basear-se na agropecuária se configura como um fator agravante à já intensa expansão das áreas de pastagens, causando fragmentação ainda maior da vegetação nativa.

Os efeitos desta fragmentação são variados e afetam as espécies em sua diversidade e quantidade, assim como em vários outros processos ecológicos (BOURLEGAT, 2003), gerando danos inclusive ao rio Aquidauana, uma vez que a retirada da mata ciliar traz consequente assoreamento de suas margens, que por sua vez desencadeia enchentes no trecho que compreende o perímetro urbano do município.

Estratégias para recuperação das áreas degradadas têm ganhado ênfase nas últimas décadas, não apenas para proteger o que resta da vegetação, mas também para buscar maneiras 
de se recuperar o que já está alterado. E, com essa atual necessidade de conservação e reposição florestal, há grande demanda de informação sobre plantas nativas, a fim de se tentar reestruturar as áreas degradadas com características mais próximas possíveis de sua composição vegetal original (POTT; POTT, 2003).

O conhecimento das espécies nativas, seja por suas aplicações fitoterápicas, alimentícias, ornamentais ou outras, vêm se perdendo ao longo do tempo, e mesmo que algumas informações sejam acessíveis, é cada vez mais difícil encontrar pessoas que detenham conhecimento sobre a flora local ou que reconheçam sua importância. Até a diferenciação entre espécies nativas e exóticas é um exercício complexo, principalmente para os mais jovens.

Nesse sentido, abordou-se ao longo do Projeto, atividades que possibilitaram o reconhecimento da flora local pelos alunos e professores da Educação Básica a fim de que ficassem mais familiarizados com o tema.

Durante os encontros semanais e usando diferentes estratégias, foram abordados diversos assuntos relacionados à flora local como: características das plantas do Cerrado, características das plantas aquáticas, adaptações das plantas aos diferentes ambientes, estratégias reprodutivas, técnicas de coleta e preservação do material botânico, uso das plantas pelo homem - extrativismo, desmatamento e uso racional das plantas, entre outros.

Algumas dessas ações estão descritas abaixo e tiveram como objetivo o despertar da curiosidade dos alunos, facilitar a compreensão de conceitos, estimular ações interdisciplinares, além de incentivar o uso de espaços alternativos no processo ensino-aprendizagem.

\subsection{ATIVIDADES DESENVOLVIDAS}

\subsubsection{CARACTERIZAÇ̃̃O DAS PLANTAS AQUÁtICAS}

Macrófitas, do grego makros = grande e phyto = planta, é a denominação genérica mais adequada e aceita pelo International Program of Biology (IBP) para designar o conjunto de vegetais "superiores" adaptados à vida em ambiente aquático ou constantemente úmido, que vão desde brejos à grandes corpos d'água (ESTEVES, 1988; POTT, 2007).

Como definição, macrófitas aquáticas são plantas visíveis a olho nu, que em algum momento de seu ciclo de vida estão completa ou parcialmente submersas ou flutuando (COOK, 1996). Originalmente são vegetais que um dia foram terrestres, mas ao longo de seu processo evolutivo, se adaptaram ao ambiente aquático e por este motivo apresentam algumas 
características de vegetais terrestres e uma grande capacidade de resiliência em períodos de seca (POTT \& POTT, 2000).

No contexto ecológico, as macrófitas aquáticas desempenham importante papel na manutenção e no funcionamento dos ecossistemas em que ocorrem (RODELLA et al. 2006), estabelecendo uma forte ligação entre o sistema aquático e o ambiente terrestre.

No Pantanal, são responsáveis pela ciclagem de nutrientes do solo durante os períodos de seca, quando a superfície inundada diminui e a matéria orgânica dessas plantas se decompõe (POTT e POTT, 2000). Também são muito importantes na cadeia trófica dos ecossistemas aquáticos pois servem como abrigo e alimento para peixes, insetos aquáticos, moluscos, aves e mamíferos, além de servirem como substrato ao perifíton (POTT \& POTT, 2009). Outra característica que agrega valor à essas espécies é sua capacidade "filtradora", fazendo a retenção de nutrientes, sedimentos e até mesmo de alguns grupos de poluentes em suspensão (HAMILTON 1993; SIPAÚBA-TAVARES et al. 2003).

Várias espécies são de interesse econômico, podendo ser usadas como apícola, ornamental, têxtil, alimentar, forrageira, medicinal, despoluidora, conservacionista, entre outros (POTT \& POTT, 2000). Um ótimo exemplo é a Eichhornia crassipes (Mart.) Solms (camalote, aguapé), que tem alto valor ornamental e ecológico, além de ser usada para confecção de esteiras, cordas, cadeiras, cortinas e outras obras trançadas (BORTOLOTTO, 2005).

Os importantes papéis desempenhados pelas macrófitas nos ambientes aquáticos e nos seus entornos, nos mostram quão ampla é a rede de interação dessas espécies. Compreender esses papéis e a importância de cada indivíduo faz a diferença para a valorização das plantas. É preciso conhecer para preservar, manter a biodiversidade e restaurar a riqueza, diversidade e qualidade desses ambientes.

No decorrer do Projeto as plantas aquáticas foram contextualizadas em diversos momentos com alunos e professores. 0 primeiro foi com uma palestra sobre as macrófitas aquáticas, abordando suas características, diversidade e importância. As demais atividades se caracterizaram com experiências "in loco", onde as informações recebidas na palestra foram enriquecidas através da realização de oficina de coleta de macrófitas do Parque Natural da Lagoa Comprida (Aquidauana-MS), visita ao Parque Estadual do Prosa (Campo Grande-MS), à Base de Estudos do Pantanal (BEP/UFMS-Corumbá) e viagem ao município de Bonito-MS. 


\subsubsection{TRILHA ECOLÓGICA GUIADA NO PARQUE ESTADUAL DO PROSA}

O Parque Estadual do Prosa foi criado em 2002 (Decreto Estadual 10.783/2002), possui pouco mais de 135 hectares dentro do perímetro urbano da cidade de Campo Grande-MS e tem como principal objetivo preservar as nascentes do córrego Prosa, amostras de ecossistemas do Cerrado (cerrado, cerradão e mata ciliar), bem como espécies da fauna e flora a ele associados. Representa uma ferramenta para a sensibilização do público em geral, visando educar as pessoas para a valorização e conservação ambiental (MS, 2011).

O Parque recebe inúmeros visitantes e possui trilhas guiadas por monitores nos remanescentes de vegetação de cerrado, cerradão e de mata ciliar.

O Cerrado é o segundo maior bioma brasileiro (SOUZA et al., 2018), caracterizado por apresentar diferentes fitofisionomias que variam na proporção dos elementos herbáceos e lenhosos que as constituem, sendo definidas como: campo limpo (apenas herbáceas), campo sujo (poucas árvores esparsas com predomínio das herbáceas), cerrado sensu stricto (predomínio de árvores baixas, tortuosas), cerradão (predomínio de árvores altas com poucas herbáceas). As florestas estacionais deciduais/semideciduais (árvores que perdem suas folhas em determinados períodos do ano) e as florestas ciliares/galeria (árvores que ocorrem nas margens de rios e córregos) pertencem ao domínio fitogeográfico do Cerrado.

A flora do Cerrado brasileiro está estimada em cerca de 7.800 espécies (SOUZA et al., 2018) e suas espécies geralmente apresentam ampla distribuição geográfica. Muitas plantas têm importância econômica, entretanto 425 espécies já são oficialmente consideradas ameaçadas de extinção (MARTINELI, 2014).

O cerrado típico possui vegetação de porte baixo, com troncos tortuosos, cascas grossas, folhas coriáceas ou quando membranáceas, muitas vezes protegidas por pelos. Não formam uma cobertura de copa contínua e assim, a radiação solar é intensa nesse ambiente. Ocorre em solos antigos, profundos, ácidos e pobres em nutrientes. 0 cerradão apresenta árvores maiores, adaptadas a solos um pouco mais férteis e tem a copa das árvores mais desenvolvidas, garantindo certo sombreamento do solo. Já as matas ciliares são constituídas por árvores altas que protegem os cursos d'água e cujas copas de uma margem do rio, não se sobrepõem sobre a outra; diferente do que ocorre nas matas de galeria, onde as copas das árvores se sobrepõem, causando maior sombreamento.

Durante o percurso na trilha no Parque do Prosa, alunos e professores receberam informações sobre algumas espécies características de cada formação vegetal (cerrado, cerradão 
e mata de galeria) e puderam sentir as diferenças no microclima, na quantidade de serapilheira no solo, na entrada de luz nos remanescentes, no tamanho e desenvolvimento dos indivíduos, nos cheiros característicos de algumas espécies, na textura das folhas e dos troncos, entre outros aspectos (Figura 1).

Figura 1. Percepção do ambiente na trilha do Parque Estadual do Prosa, Campo Grande/MS.
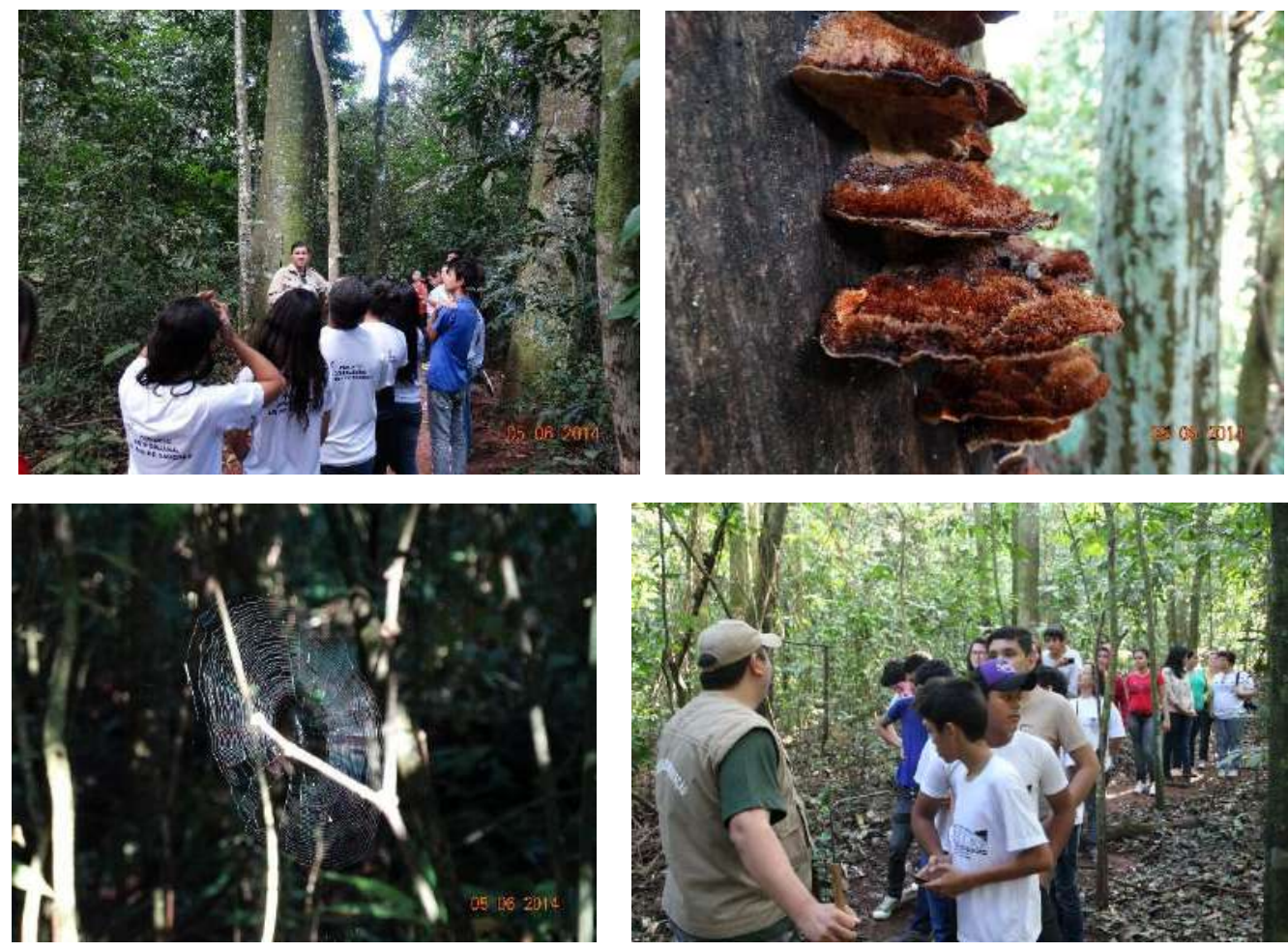

\subsubsection{TRILHA, COLETA E HERBORIZAÇÃO NA BASE DE ESTUDOS DO PANTANAL (BEP)}

A Base de Estudos do Pantanal (BEP) está localizada na margem direita do Rio Miranda, na região denominada "Passo do Lontra" (entre o Pantanal do Miranda e do Abobral) no município de Corumbá-MS. Possui estrutura com alojamento, refeitório e laboratórios. As atividades de ensino, pesquisa e extensão são regularmente desenvolvidas, proporcionando muitas aprendizagens a todos que dela usufruem.

O Pantanal representa a maior planície de inundação contínua do Planeta. Caracteriza-se pela baixa altitude, baixa declividade e ocorrência de alagamentos periódicos, entretanto não é um grande pântano, mas sim uma mistura heterogênea de diversas formações vegetais, com afinidade maior com a flora do Cerrado, mas também influenciado pelo Chaco, Mata Atlântica e Floresta Amazônica (POTT; POTT, 1997). 
Sua elevada diversidade decorre dessa interação entre os diferentes ecossistemas, aliado ao pulso de inundação, que proporciona grande variação temporal e espacial da paisagem (POTT; POTT, 1997). Assim, o Pantanal pode ser classificado em diversas sub-regiões de acordo com suas características de solo, topografia, periodicidade e intensidade das inundações e composição florística (SILVA; ABDON, 1998).

Durante a visita à BEP foram realizadas duas trilhas com os alunos e professores, os quais puderam reconhecer a flora nativa do Cerrado e do Pantanal, bem como suas espécies predominantes.

A primeira trilha foi na fisionomia de cerrado sensu stricto, onde além do reconhecimento de espécies típicas, os alunos puderam aprender sobre as técnicas de coleta e herborização do material botânico (IBGE, 2012). Para a coleta usaram tesoura de poda alta e tesoura de mão, acondicionaram as plantas nos sacos de coleta, anotaram suas características e depois, já no laboratório da BEP, fizeram as prensas e colocaram o material na estufa para secagem. Ao longo da trilha e no laboratório também foram utilizados guias de campo (POTT; POTT 1997; 2000; LORENZI 2002a, 2002b) para reconhecimento e identificação das espécies.

A segunda trilha foi realizada sobre as baías do rio Miranda, em palafitas, onde foi possível observar a vegetação aquática característica do Pantanal, sendo reconhecidas por eles o aguapé, camalote e orelha de onça, já observadas em atividades anteriores, entre outras novas espécies (Figura 2).

Em sala de aula e no laboratório foram trabalhadas algumas características das plantas que evidenciavam sua adaptação aos diferentes ambientes. A “descoberta" das plantas, principalmente as aquáticas, foi motivo de grande satisfação para os professores/monitores do Projeto, uma vez que muitas delas, ainda que "comuns" não são percebidas/compreendidas pela maior parte das pessoas. 
Figura 2. Trilhas na Base de Estudos do Pantanal, Miranda/MS.

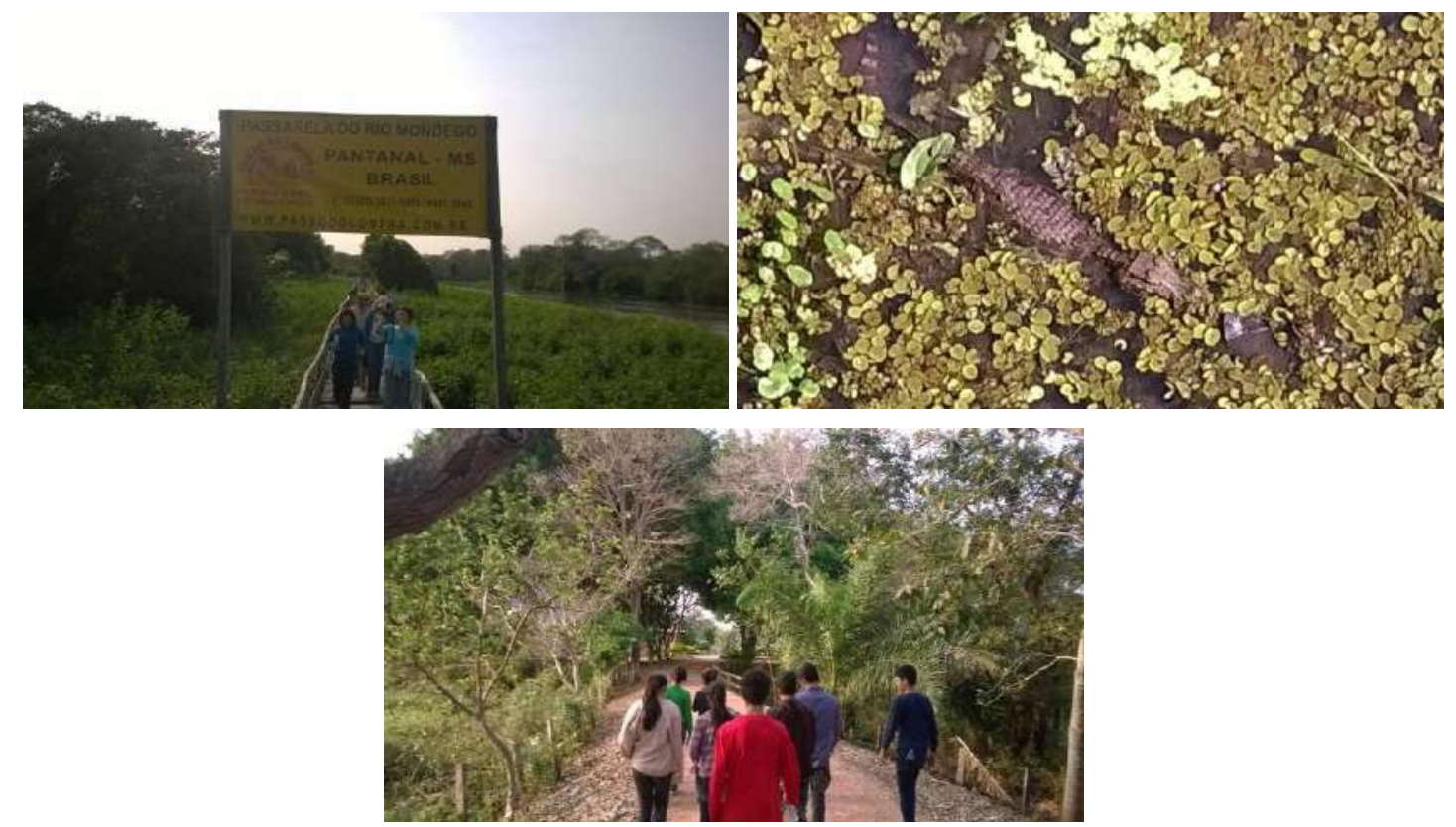

\subsection{RELATO DOS MONITORES DO PROJETO}

A experiência de trabalhar em um projeto dessa magnitude no período da faculdade é um privilégio que deveria ser oferecido a todos os acadêmicos. Em uma graduação em licenciatura é indispensável que tenhamos esse contato verdadeiro com os estudantes, podendo entender como funciona a aprendizagem e os mecanismos que podem ser utilizados para ajudar nesse processo.

No projeto, realizamos palestras para os estudantes, apresentando uma parte teórica do que posteriormente seria observado na prática nas diversas atividades que foram desenvolvidas com os alunos.

Foi extremamente enriquecedor poder observar o encantamento das crianças com tudo que foi proposto, já que o projeto trouxe uma nova perspectiva de aulas, bem diferentes daquelas que são oferecidas nas escolas convencionais.

Na visita que fizemos ao CRAS (Centro de Reabilitação de Animais Silvestres) tivemos a oportunidade de conhecer diversas espécies de animais silvestres que não havíamos observado pessoalmente antes, incluindo um espécime de anta albina (Tapirus terrestres) que, com certeza, foi a grande atração daquele dia. Além disso, o Parque do Prosa, local onde situa-se o CRAS, conta com uma vasta flora, típica do cerrado-pantanal, onde conseguimos observar espécies vegetais que já havíamos trabalhado com os estudantes em aulas teóricas. 
Na viagem que fizemos a Base de estudos do Pantanal - UFMS, conseguimos unir em uma grandiosa aula prática, tudo o que havíamos transmitido para os estudantes nos nossos encontros anteriores. Equipados com toda a segurança necessária, os próprios alunos utilizaram as ferramentas (podão e tesoura de poda de mão) para fazer a coleta dos exemplares e também anotaram em suas planilhas as informações relevantes sobre o que estava sendo coletado. Ao voltarmos para a Base, os monitores juntamente com os alunos fizeram a prensa do material coletado que foi levado para a estufa para posteriormente ser identificado.

Todas essas experiências enriqueceram e muito a vida dos nossos estudantes, pois a maioria não teria a oportunidade de desenvolver essas atividades se não fosse pelo Projeto. Nós monitores, também conseguimos observar de forma incisiva e na prática, como mecanismos diferenciados na forma de ensinar, a realização de aulas práticas e atividades dinâmicas, conseguem abrir caminhos para a aprendizagem e concretizar o conhecimento nos alunos.

Esse projeto, foi sem dúvida, um dos pontos altos na vida acadêmica, deixando um grande legado nossa formação profissional e reiterando mais uma vez, a vontade de transmitir conhecimentos, buscando sempre os meios mais eficazes para que isso aconteça.

\subsection{CONSIDERAÇ̃̃ES FINAIS}

Enfatizamos aqui a importância das atividades externas como estímulo ao processo de apreensão do conhecimento. Sabemos que nem sempre é possível a realização de viagens e exploração de espaços externos como os realizados no Projeto, proporcionados pelo apoio financeiro recebido da CAPES (Coordenação de Aperfeiçoamento de Pessoal de Nível Superior). Entretanto, ressaltamos que qualquer atividade diferenciada fora da sala de aula, seja na observação das plantas no pátio da escola, no quarteirão que a rodeia, em algum parque do município ou mesmo no quintal das suas próprias casas, pode transformar-se em estímulo para uma aprendizagem significativa.

O encantamento e principalmente o aprendizado ficaram registrados nas atividades de leitura e produção de texto, aplicadas ao término de cada abordagem realizada.

Entende-se que os principais objetivos das diferentes atividades realizadas foram alcançados uma vez que a curiosidade e a sensibilização de todos participantes (professores, monitores e alunos da educação básica) foram efetivas e a aprendizagem se tornou significativa para muitos deles. 


\section{REFERÊNCIAS BIBLIOGRÁFICAS}

BORTOLOTTO, I. M.; GUARIM, N. G. O uso do camalote, Eichhornia crassipes (Mart.) Solms, Pontederiaceae, para confecção de artesanato no Distrito de Albuquerque, Corumbá, MS, Brasil. Acta Botanica Brasilica. Vol. 19, n. 2. 2005.

BOURLEGAT, C. A. Le. A fragmentação da vegetação natural e o paradigma do desenvolvimento rural. In: Fragmentação florestal e alternativas de desenvolvimento rural na região Centro-Oeste. Org. Reginaldo Brito da Costa. Campo Grande: UCDB. P. 01-25, 2003.

COOK, C. D. K. Aquatic and Wetland Plants of India. Oxford University Press. New York, 1996.

ESTEVES, F. A. Fundamentos de Limnologia. Interciência/FINEP. Rio de Janeiro, 1988.

HAMILTON, S. K. Características limnológicas de importância para as plantas aquáticas no Pantanal. In: Resumos do II ENBOC - CEUC/UFMS. Sociedade Brasileira de Botânica. Brasília, 1993.

IBGE. Manual técnico da vegetação brasileira: sistema fitogeográfico; inventário das formações florestais e campestres; técnicas e manejo de coleções botânicas; procedimentos para mapeamentos. Rio de Janeiro: IBGE, 272 p., 2012.

LORENZI, H. 2002a. Árvores brasileiras: Manual de identificação e cultivo de plantas arbóreas nativas do Brasil. Nova odessa: Editora Plantarum, 1998. volume 1.

LORENZI, H. 2002b. Árvores brasileiras: Manual de identificação e cultivo de plantas arbóreas nativas do Brasil. Nova odessa: Editora Plantarum, 1998. volume 2.

MARTINELLI, G. et. al. Livro vermelho da flora do Brasil, Plantas raras do cerrado. Rio de Janeiro. CNCFlora, Instituto de Pesquisas Jardim Botânico do Rio de Janeiro. 2014.

MS. Secretaria de Estado de Meio Ambiente, Planejamento, da Ciência e Tecnologia de Mato Grosso do Sul. Plano de Manejo do Parque Estadual do Prosa. Org. Nascimento, A.C. S; Moura, F. N.; Torrecilha, S. Campo Grande, 75 p., 2011.

POTT, A; POTT, V. Plantas do Pantanal. Embrapa. Brasília, 1997.

POTT, V. J.; POTT, A. Plantas aquáticas do Pantanal. Embrapa. Brasília, 2000.

POTT, A; POTT, V. J. Espécies de fragmentos florestais em Mato Grosso do Sul. IN: COSTA, R. B. (org.). Fragmentação florestal e alternativas de desenvolvimento rural na região centro-oeste. UCDB, Universidade Católica Dom Bosco, 2003.

POTT, V. J. Plantas aquáticas do Pantanal e da Alta Bacia. In: Congresso De Ecologia Do Brasil: Anais. Sociedade de Ecologia do Brasil. Caxambu. 2007.

POTT, V. J.; POTT, A. Macrófitas aquáticas do Pantanal e áreas úmidas em Mato Grosso do Sul. In: III CLAE e IX CONGRESSO DE ECOLOGIA DO BRASIL: Anais. São Lourenço, 2009. 
RODELLA, R. A.; COSTA, N. V.; COSTA, L. D. N. C.; MARTINS, D. Diferenciação entre Egeria densa e Egeria najas pelos caracteres anatômicos foliares. Planta Daninha. Vol. 24, n. 2., p.211220, Viçosa, 2006.

SILVA, J. F. da.; JOIA, R. P. Territorialização e Impacto Ambiental: Um estudo da Zona Ribeirinha de Aquidauana-MS. Revista Pantaneira. Vol. 3, n. 1., p. 17-30 Aquidauana, 2001.

SILVA, J.D.S.V \& ABDON, M.M. Delimitação do Pantanal brasileiro e suas sub-regiões. Brasília: Pesq. agropec. bras., v.33, Número Especial, p.1703-1711, 1998.

SIPAÚBA-TAVARES, L. H.; BARROS, A. F.; BRAGA, F. M. S. Effects of floating macrophyte cover on the water quality in fishpond. Acta Scientiarum. vol. 25, n.1., p. 101-106 Maringá, 2003.

SOUZA, V.C.; FLORES, T. B.; COLLETA, G.D.; COELHO, R.L.G. Guia das plantas do cerrado. Piracicaba, SP: Taxon Brasil Eidtora e Livraria, 2019. 583 p. 


\section{CAPITULO VI}

\section{EDUCAÇÃO AMBIENTAL NA FORMAÇÃO DO CIDADÃO ECOLÓGICO}

Elisangela Castedo Maria do Nascimento ${ }^{1}$ Idevando de Arruda Lino ${ }^{2}$

1. Docente substituta no Curso de Pedagogia, Universidade Federal de Mato Grosso do Sul, Campus de Aquidauana, Rua Oscar Trindade de Barros, 740, Bairro da Serraria, Aquidauana, MS, Brasil, 79200-000.

2. Graduado em Pedagogia, Universidade Federal de Mato Grosso do Sul, Campus de Aquidauana, Rua Oscar Trindade de Barros, 740, Bairro da Serraria, Aquidauana, MS, Brasil, 79200-000.

Geralmente as pessoas possuem um pensamento naturalista da realidade, sem levar em consideração as relações e conexões da vida biológica e socioambiental existentes entre o ser humano e natureza.

Carvalho (2006) alerta para "as vendas" vitimadas dos olhares que conceituam a natureza como intocada e sem relação com o homem. É necessário que se conteste estes conceitos préestabelecidos numa iniciativa para a mudança de visão, como um detetive ao utilizar-se de uma lupa para investigar e descobrir as provas reais que se mantêm invisíveis ao olho nu, amplia-se o sentido visual e relaciona-se os saberes em sua totalidade, possibilitando enxergar com clareza e precisão o contexto no qual se vive.

Desprender-se de ideais e conceitos ditos universais é o primeiro passo para se apropriar e contextualizar novas formas de compreensão da relação sociedade/natureza. Sobre isto, a visão socioambiental propõe revelar vínculos colaborativos ecológicos entre os seres humanos e a natureza, bem como romper com o pensamento preservacionista, característico da concepção humana do pensamento tradicional naturalista e assumir uma nova postura na compreensão dos problemas ambientais (CARVALHO, 2006).

Visando romper esse pensamento preservacionista e naturalista Carvalho (2006) acredita que na formação do cidadão tenha que se levar em consideração a racionalidade complexa e interdisciplinar que é caracterizada por abranger o conhecimento em sua totalidade e não reduzir, fragmentar este saber em "compartimentos ou gavetas". Esta concepção propõe 
uma formação interdisciplinar voltada para ação e minimização dos impactos ambientais diários objetivando pequenos feitos, mas com grandes efeitos.

Um dos objetivos da Educação Ambiental é a criação e ampliação de formas sustentáveis na relação sociedade natureza, além de buscar soluções para os problemas ambientais, garantind o condições necessárias para a sobrevivência das gerações futuras. O que se busca com a Educação Ambiental, então, é formar essa consciência de mudança do presente para construir um futuro no qual as pessoas tenham atitudes e comportamentos responsáveis, vivendo e convivendo como cidadãos planetários. Em relação à consciência, Freire (1979) diz que não existe conscientização sem ação-reflexão.

Dessa forma, o objetivo principal do projeto foi aproximar alunos e professores do ensino fundamental de duas escolas da rede pública do município de Aquidauana com acadêmicos e professores do ensino superior, de vários cursos da Universidade Federal de Mato Grosso do Sul, por meio de aulas teóricas, oficinas, aulas práticas em laboratório, aulas de campo e visitas técnicas, a fim de contribuir para uma formação dinâmica e interativa.

Seis professores da educação básica da rede estadual de ensino, das áreas de ciências, português e geografia participaram do projeto e foram responsáveis pela seleção de 25 alunos matriculados no sexto e sétimo ano do ensino fundamental, em função do conteúdo estudado nessas etapas estarem relacionados às questões ambientais.

\footnotetext{
O trabalho desenvolvido pelas Universidades, Organizações governamentais e não governamentais na área ambiental é um valioso instrumento para o ensino e aprendizagem do tema meio ambiente. A relação com as instituições próximas a escola pode resultar em simples colaboração ou em significativas parcerias para a execução de ações conjuntas (BRASIL, 1998, p. 192).
}

A atuação dos educadores e educandos da universidade juntamente com a escola, trouxe para ambos a troca de saberes e ideias, levando o aluno a conhecer, visualizar, contextualizar e assimilar o conhecimento prévio como o novo, numa decifração da realidade. E neste contexto é que se concretiza uma aprendizagem significativa do conteúdo estudado.

Foram realizados encontros semanais por 21 meses (2013 a 2015) para o desenvolvimento das ações de estudo teórico e prático: palestras, oficinas de elaboração de cartazes, demonstrações científicas, participação em mostras e feiras, aulas de campo e aulas práticas nos laboratórios de biologia, geografia e informática. As aulas eram ministradas com o auxílio de monitores, que também ajudavam com a organização dos materiais didáticos. Cada exercício realizado se transformava numa integração de conhecimento, reflexões, questionamentos e esclarecimentos que tinha como tema gerador o Rio Aquidauana. 


\subsection{ATIVIDADES DE EDUCAÇÃO AMBIENTAL DESENVOLVIDAS}

No dia Mundial da água, 22 de março, foi ministrada na UFMS/CPAQ uma aula sobre a importância e função da água na composição química dos organismos vivos, assim como foi abordado o desperdício, a poluição, o saneamento básico, a saúde e ações de conservação da água. Em sala, propôs-se aos alunos que recortassem figuras específicas relacionadas ao tema para elaborar cartazes, retratando o desperdício e o consumismo exorbitante em nossa sociedade. Após elaboração dos cartazes, houve a exposição e apresentação nas escolas parceiras do projeto.

Após cada aula teórica os alunos faziam atividades como caça-palavras, cruzadinhas e respondiam perguntas que nos davam a dimensão da aprendizagem fixada. A cada atividade realizada, eles também tiravam fotos com seus celulares e salvavam em uma pasta. As fotografias tiradas no desenvolvimento do projeto e as produções de texto feitas em aulas foram usadas na elaboração de roteiros e produção de vídeos de divulgação sobre tudo o que foi desenvolvido e aprendido no decorrer do projeto.

No laboratório de informática da UFMS/CPAQ, os alunos colocaram as fotos em sequência no Power point e escreveram o texto para produção do vídeo (Figura 1), que foi finalizado após a última atividade no município de Corumbá, com a visita ao Museu de História do Pantanal, Estação Natureza Pantanal e descida de Chalana no Rio Paraguai. 
Figura 1. Atividades de produção de texto e confecção de vídeos no laboratório de informática da UFMS/CPAQ.
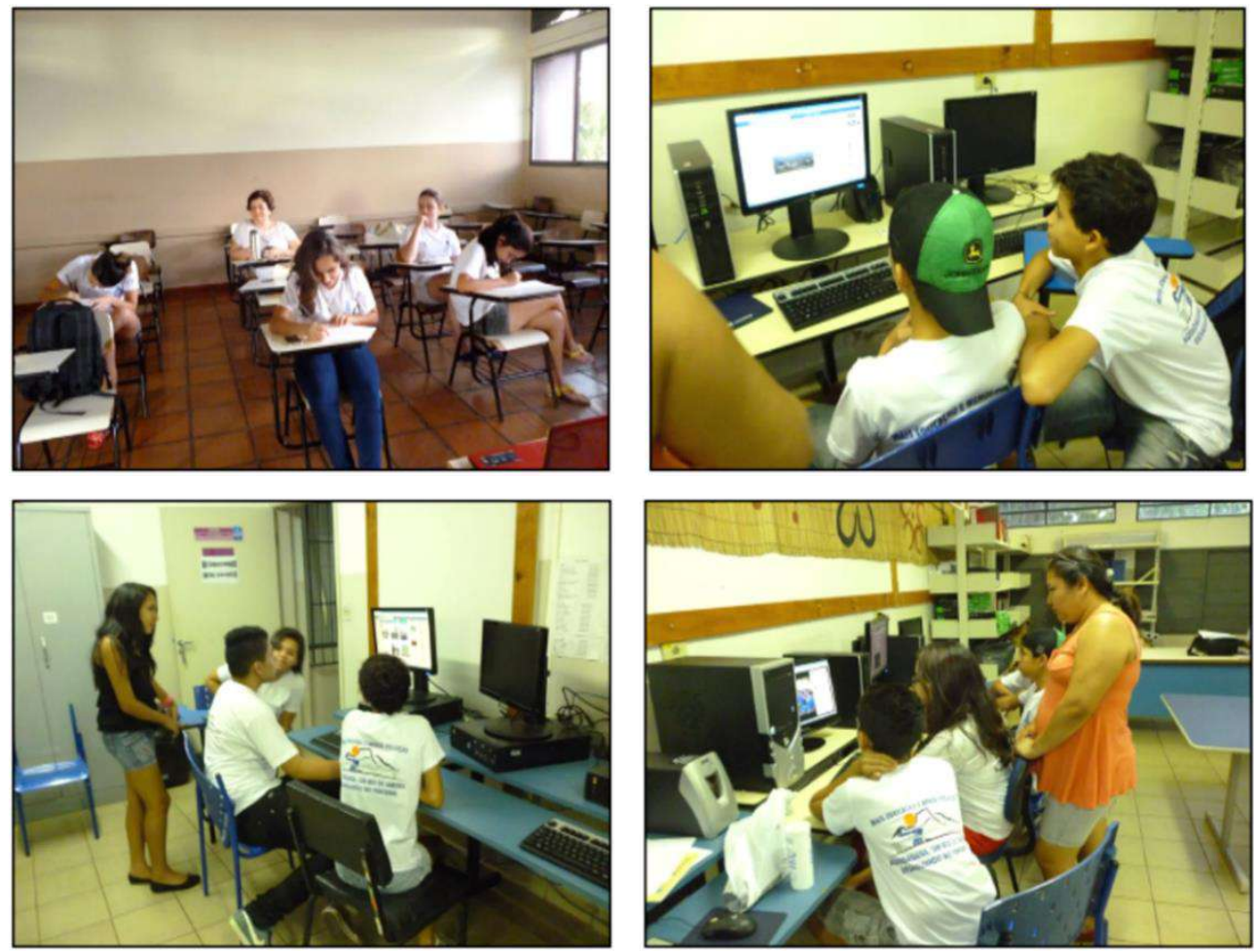

Para uso do laboratório de informática de forma mais proveitosa, os alunos foram divididos em dois grupos (A e B), sendo que primeiramente o grupo A foi para sala de aula, onde um dos monitores do curso de Pedagogia ministrou palestra referente ao Cerrado e Pantanal: suas características; localização geográfica; aspectos do clima; ação humana sobre os ambientes; sua fauna, destacando os animais que o habitam e que são vistos no cotidiano de quem frequenta a região; as plantas predominantes, num panorama geral da biodiversidade e da compreensão de que

Mato Grosso do Sul é coberto por dois principais biomas, Cerrado e Pantanal, que ocupam extensas áreas e juntos constituem mosaicos de vegetação bastante complexos. Em função da grande extensão territorial, a composição florística é bastante diversificada, uma vez que as plantas são elementos fixos e só ocorrem em locais onde estão adaptadas às características ambientais (FINA, 2015, p.15).

Logo esta temática tem uma relevante abordagem para caracterizar, compreender, contextualizar, significar a localidade geográfica e cultural a qual o aluno pantaneiro está inserido, possibilitando a construção de identidade e valorização do ambiente regional.

Em continuação às atividades, o grupo $B$ foi para a sala de tecnologia, onde foram orientados a selecionar as fotos oriundas do projeto no programa Powerpoint para a produção de vídeos no programa Movie Maker. Este vídeo se fundamentou em registrar os momentos de 
aprendizagem, as sensações, emoções e experiências construídas durante os encontros; nas aulas de campo, viagens, entre outras atividades.

Posteriormente as turmas se revezaram e assim todos os alunos aprenderam a usar o programa e desenvolveram a edição do vídeo. No total foram produzidos oito vídeos, que foram apresentados aos demais colegas.

Ao final do projeto, distribuiu-se uma atividade de produção de texto para os educandos descreverem suas conclusões a respeito das aulas de campo desenvolvidas. De acordo com Brasil (1998, p. 231) é importante “Aplicar um enfoque interdisciplinar, aproveitando o conteúdo específico de cada área, de modo que se consiga uma perspectiva global da questão ambiental".

\subsection{CONSIDERAÇÕES FINAIS}

Essa vivência educativa fez parte de uma postura interdisciplinar de construção do conhecimento e elaboração de novas hipóteses. Os alunos puderam trocar as lentes do conhecimento, "isso significa sair dos lugares habituais que se pretende universais, de onde aprendemos a olhar as coisas e identificá-las de um único ponto de vista” (CARVALHO, 1998, p.19), e ao se deparar com outras realidades, passaram a ter um olhar diferente e a buscar soluções de problemas com criatividade.

Em síntese, a prática educativa ambiental se constitui em práxis do conhecimento como afirma Paulo Freire (1989, p.67) “A teoria sem a prática vira 'verbalismo', assim como a prática sem teoria vira ativismo, no entanto quando se une a prática com a teoria tem-se a práxis, a ação criadora e modificadora da realidade`. Com base nessa reflexão fica compreendida a dimensão de conhecimentos que a EA visa para a formação do cidadão ecológico.

0 vídeo confeccionado representou um resumo de todo aprendizado que tiveram durante o projeto com enfoque na água, saúde, clima, solo, topografia, hidrologia, relevo, território, paisagem, fauna, flora, biomas, cultura e impactos ambientais.

Nesse projeto a Educação Ambiental foi pensada “como forma de estabelecer um diálogo interdisciplinar na tentativa de primeiro alertar e depois modificar os valores e atitudes, permitindo a reflexão crítica e a capacidade de participação na vida social” (NASCIMENTO, 2015, p. 25). Foi oferecido aos alunos um ambiente propício à reflexão, à ação, ao aprender e a construção de novas experiências.

A concepção de educação neste projeto foi pautada numa prática problematizada de reflexão e ação da realidade, na construção do conhecimento do educando, tendo uma visão de 
mundo e não uma prática "bancária" que deposita no educando um conteúdo pragmático sem fundamento, nem propósito (FREIRE, 1987).

Foi priorizada uma prática transversal onde o professor se apropria de novas metodologias e recursos didáticos para contribuir na formação dos educandos, permitindo a integração e interação da comunidade escolar em geral, visto que os temas selecionados priorizaram o conhecimento de mundo além de descrever a realidade na qual se situam.

Deste modo, buscamos na concepção de Freire (1987) dar um passo à frente na adesão de mudança, de renovação, de aprendizagem e produção de conhecimentos baseados na reflexão e visão do mundo, bem como, uma ação dialógica com a comunidade escolar, com o comprometimento com uma educação problematizadora da realidade e revolucionária que abarca o saber em sua dimensionalidade e complexidade, produzindo um rico conhecimento cultural, cheio de valorização e comprometimento com um futuro melhor.

\section{REFERÊNCIAS BIBLIOGRÁFICAS}

BRASIL. Parâmetros Curriculares Nacionais: Terceiro e quarto ciclos: Apresentação dos temas transversais, Meio ambiente. Secretaria de Educação Fundamental. Brasília: MEC/SEF, 1998.

CARVALHO, I. C.de M. Educação ambiental: a formação do sujeito ecológico; São Paulo: Cortez, 2.ed. 2006.

. Em direção ao mundo da vida: interdisciplinaridade e Educação ambiental - Brasília: IPÊ - Instituto de Pesquisas ecológicas. Brasília, 1998.

FINA, B. G.; AOKI, C.; LUZ, D. F. (Orgs). Projeto Aquidauana: Um rio de saberes desaguando no Pantanal. Aquidauana: MCelestiné, 47 p. 2015.

FREIRE, P. Pedagogia do oprimido, 17. ed. Rio de janeiro, Paz e Terra, 1987.

Pedagogia da autonomia: saberes necessários à prática educativa. $45^{\underline{a}} \mathrm{ed}$ - - Rio de janeiro: Pais e Terra, 2013.

Educação como prática da liberdade. Paz e Terra, 1989.

Conscientização: Teoria e prática da libertação, uma introdução ao pensamento de Paulo Freire. São Paulo: Cortez \& Moraes, 1979.

NASCIMENTO, E. C. M. do. Educação Ambiental. In: FINA, B. G.; AOKI, C.; LUZ, D. F. (Orgs). Projeto Aquidauana: Um rio de saberes desaguando no Pantanal. Aquidauana: MCelestiné, 47 p., 2015. 


\section{CAPITULO VII}

\section{RELATOS DE EXPERIÊNCIAS COM A DISCIPLINA DE CIÊNCIAS}

Vicenta de Oliveira Alvarenga

Professora da Educação Básica, Secretaria de Estado da Educação, bióloga pela Universidade Federal de Mato Grosso do Sul, Campus de Aquidauana, Rua Oscar Trindade de Barros, 740, Bairro da Serraria, Aquidauana, MS, Brasil, 79200-000

O ensino de Ciências é fundamental para que o aluno desenvolva competências que lhe permitam compreender o mundo e atuar como indivíduo e como cidadão, utilizando conhecimentos de natureza científica e tecnológica; sendo assim, observou-se a necessidade de buscar mecanismos para conquistar os estudantes, transmitir os conhecimentos necessários e alcançar um ensino aprendizado satisfatório.

Nesse contexto, percebi que precisava dar um sabor e sentido às aulas de ciências, tendo em vista que os alunos do $7^{0}$ ano da E.E. Prof. Antônio Salústio Areias, se mostravam desinteressados com os conteúdos curriculares, principalmente com a disciplina de ciências, gerando no contexto escolar a falta de limites e indisciplina, além da não realização das atividades propostas pelos professores, o que consequentemente iria contribuir para resultados negativos ao final do ano letivo.

Diante de tantos desafios percebemos que a escola tem passado por situações de tensão e conflitos permanentes e que muitas vezes fogem do objetivo final - a educação e preparação para a vida em sociedade. A indisciplina e a falta de motivação tem sido uma das maiores dificuldades enfrentadas pelos professores para desenvolverem o trabalho pedagógico.

Segundo Vasconcelos (1996), a maior queixa dos professores em relação aos alunos é a falta de interesse desses, além de citarem também o avanço da tecnologia, que veio evidenciar a falta de domínio do professor, que está acostumado a usar o giz e o apagador para ministrar suas aulas. 
As exigências tecnológicas do mundo moderno vêm com muita velocidade trazendo informações que determinam as relações de poder (informação é poder), obrigando a escola a se modernizar para acompanhar esse processo. Somente quadro e giz já não satisfazem a curiosidade das crianças, que desde cedo convivem com brinquedos eletrônicos, vídeo games, celulares e até computadores.

Para Chalita (2009, p.77) uma sala de aula tem um pouco de tudo isso. Os alunos são absolutamente diferentes; podem rir de qualquer coisa, tentam chamar atenção, todos querem ser vistos e procuram mecanismos para serem lembrados.

Em 2013, passei por uma experiência inovadora quando a Escola Estadual Antônio Salústio Areias recebeu convite da Universidade Federal de Mato Grosso do Sul/Campus de Aquidauana para fazer parte do Projeto "Aquidauana: um Rio de Saberes desaguando no Pantanal”. Na ocasião teríamos que selecionar alguns estudantes para compor o grupo que, junto de outros estudantes da Escola Estadual Marechal Deodoro da Fonseca, fariam parte do Projeto.

Para que pudéssemos selecionar os estudantes foram seguidos alguns critérios, e um dos pontos principais seria gostar ou ter afinidade com as aulas de ciências, ter assiduidade e responsabilidade.

Um fator muito importante na escolha foi o de não buscar apenas alunos que se destacavam na escola por apresentarem boas notas bimestrais ou os ditos "melhores" estudantes. Com isso surgiu a oportunidade para aqueles que estavam sempre presentes na escola, mas que na maior parte das aulas estavam desmotivados.

Muitas das atividades desenvolvidas, viagens, visitas aos museus e o mergulho no rio Formoso, ficaram marcadas na vida de cada estudante e também dos professores que fizeram parte do projeto (Figura 1). Nossos alunos tiveram oportunidade de conhecer a flora, a fauna, os rios e principalmente desenvolver trabalhos em equipe, trazendo mudanças significativas para cada jovem, que com isso, passaram a valorizar as aulas e também entender que a teoria é muito importante, pois é a partir dela que se oferece a base para aplicar na realização das aulas práticas. 
Figura 1. Diferentes atividades desenvolvidas no decorrer do Projeto de Extensão.
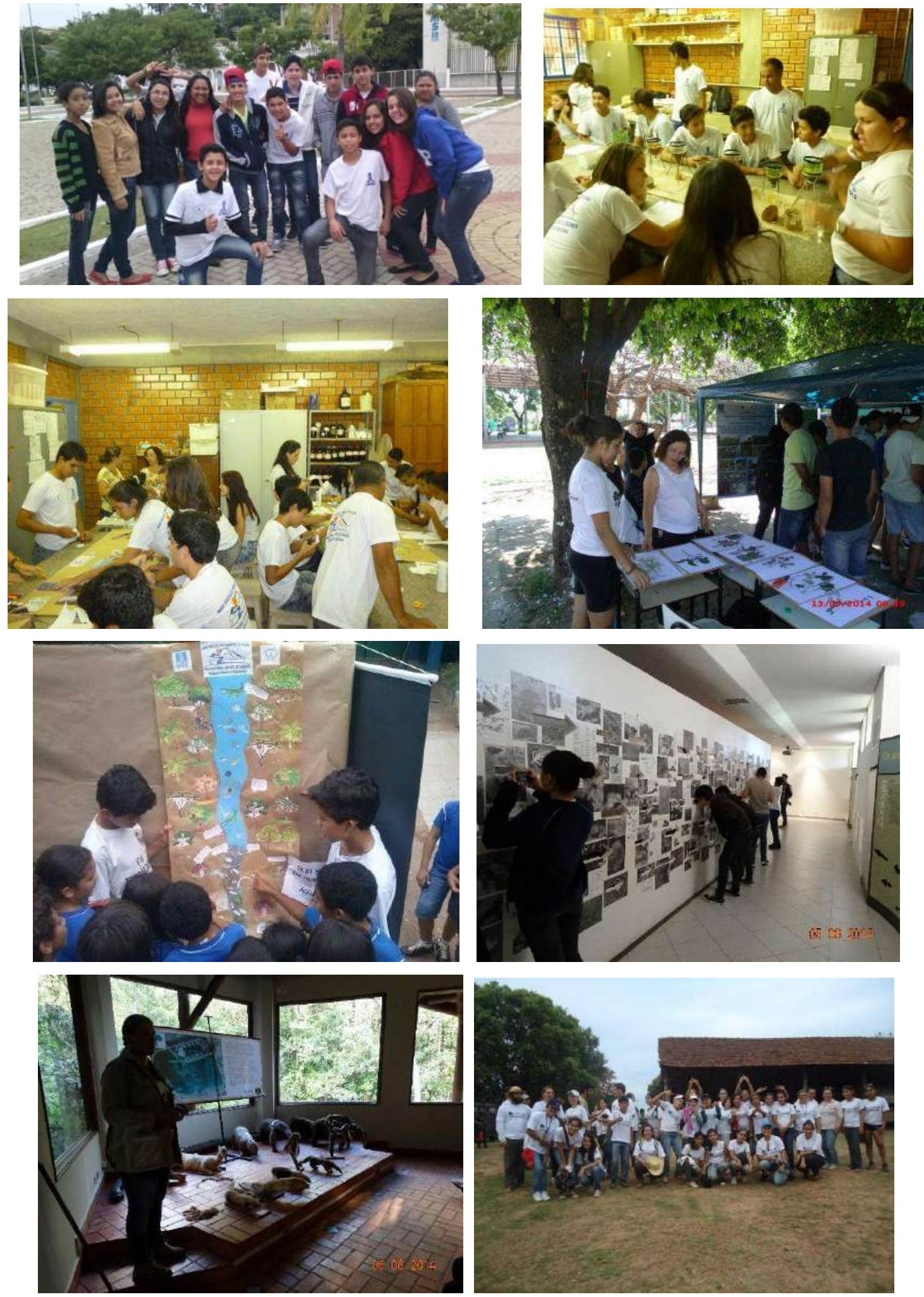

Vale ressaltar que a cada atividade desenvolvida no projeto fui percebendo a mudança de comportamento por parte dos estudantes. Passaram a ser participativos, responsáveis e comprometidos com cada procedimento realizado. 
A partir do desenvolvimento do projeto os estudantes tiveram a oportunidade de realizar pesquisas e produção de texto, que foram importantes para o ensino e aprendizagem. $\mathrm{E}$ a cada encontro, viagem e atividades realizadas percebia-se o interesse e a expectativa para as novas práticas e aulas de campo. Com isso passaram a ter novos assuntos dentro da sala de aula que sempre girava em torno dos trabalhos realizados ou das viagens que haviam participado. Dessa forma passaram a ser multiplicadores das atividades desenvolvidas, aguçando o interesse de outros estudantes a virem a participar de projetos desenvolvidos nas escolas e em outras instituições. Todos esses fatores favoreceram o aprendizado, assim como o bom relacionamento entre professores e estudantes.

Portanto, concluímos que os educadores precisam olhar os novos horizontes, buscar novas alternativas para levar os estudantes ao interesse, compromisso e disciplina no decorrer das aulas semanais. Esquecer um pouco do giz e livros didáticos e se mostrarem mais humanos e generosos. Para Chalita (2009, p.61), escolher ser professor, por decisão ou vocação, é assumir um compromisso com a formação do ser humano. Quem ensina alguma coisa a alguém experimenta a generosidade.

\section{REFERENCIAIS BIBLIOGRÁFICAS}

BENETTE, T. S. \& COSTA, L. P. Indisciplina na sala de aula: Algumas Reflexões, 2009. Disponível em: <http://www.diaadiaeducacao.pr.gov.br/portals/pde/arquivos/21868.pdf>. Acesso em: 15/04/2020.

CHALITA, G. Semeadores da esperança: uma reflexão sobre a importância do professor. São Paulo: Ciranda Cultural, 2009. Coleção cultivar.

GUIMARÃES, L. R. - Série professor em ação: atividades para aulas de ciências: ensino fundamental, 6 ao 9 ano. 1 ed. São Paulo: Nova Espiral, 2009.

VASCONCELOS, C. dos S. - Os desafios da indisciplina em sala de aula e na escola - Apostila do Curso Orientações e Sugestões para o Coordenador Pedagógico sobre os Referenciais Curriculares - Campo Grande, 2008. 


\section{EXTENSÃO UNIVERSITÁRIA \\ UM CAMINHO DE INTEGRAÇÃO E APRENDIZAGEM}

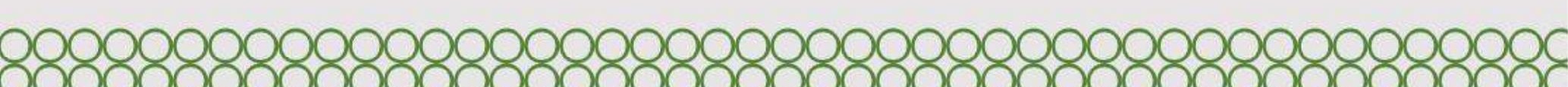

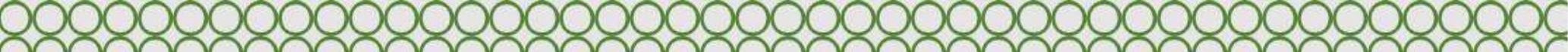

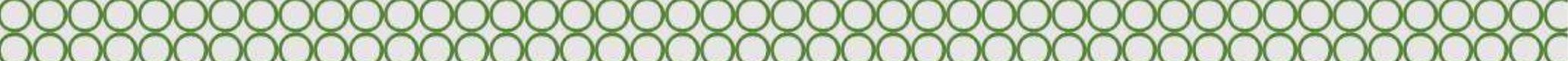
 8, 8, D

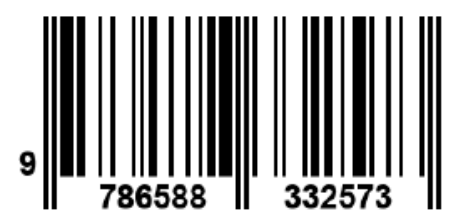

